\title{
The Spg1p GTPase is an essential, dosage-dependent inducer of septum formation in Schizosaccharomyces pombe
}

\author{
Susanne Schmidt, ${ }^{1}$ Marc Sohrmann, ${ }^{1}$ Kay Hofmann, ${ }^{2}$ Alison Woollard, ${ }^{3,4}$ and Viesturs Simanis ${ }^{1,5}$ \\ ${ }^{1}$ Cell Cycle Control Laboratory and ${ }^{2}$ Biocomputing Unit, Swiss Institute for Experimental Cancer Research (ISREC), 1066 \\ Epalinges, Switzerland, ${ }^{3}$ Imperial Cancer Research Fund (ICRF), Cell Cycle Control Laboratory, London WC2A 3PX UK
}

The spg1 gene (septum-promoting GTPase) was cloned as a multicopy suppressor of a dominant-negative mutant of the Cdc7p kinase. It encodes a small GTPase of the Ras superfamily. spg1 is an essential gene. Null or heat-sensitive alleles do not make a division septum, but growth, S-phase, and mitosis continue in the absence of cell division, producing elongated, multinucleate cells. Increased expression of Spg1p induces septum formation in $G_{2}$, S-phase, and pre-Start $G_{1}$-arrested cells. This requires the activity of Cdc7p kinase, but not $\mathrm{p}^{\text {cdc2 }}$. Increased expression of Cdc7p bypasses the requirement for Spg1p. Spg1p and Cdc7p can be coimmunoprecipitated from cell extracts, and interact in the two-hybrid system. These data indicate that Spg1p is a key element in controlling the onset of septum formation in Schizosaccharomyces pombe, and that it acts through the Cdc7p kinase.

[Key Words: Cytokinesis; G-protein; kinase; cell cycle; mitosis]

Received February 7, 1997; revised version accepted April 22, 1997.

Premature initiation of cytokinesis can lead to loss of chromosomes, or even "cutting" of the nucleus (e.g., see Hirano et al. 1986). Therefore, the proper spatial and temporal coordination of mitosis and cytokinesis is essential for maintaining the integrity of the genome. A combination of biochemical and genetic approaches has identified regulators of mitosis and structural components of the mitotic apparatus and cleavage furrow /for review, see Forsburg and Nurse 1991; Satterwhite and Pollard 1992; Fishkind and Wang 1995). However, although much is known about the events that occur during mitosis and cytokinesis, the details of the mechanisms coordinating them remain elusive. The fission yeast Schizosaccharomyces pombe provides a simple eukaryotic system to study these processes (for review, see Simanis 1995).

Fission yeast cells grow mainly by elongation at their tips and divide by binary fission after forming a centrally placed septum. As in higher eukaryotes, initiation of cytokinesis is dependent on the onset of mitosis (Minet et al. 1979). In S. pombe, F-actin is seen as patches or dots at sites of cell growth or division. During interphase, it is

\footnotetext{
${ }^{4}$ Present address: MRC Laboratory of Molecular Biology, Cell Biology Division, Cambridge CB2 2QH, UK.

${ }^{5}$ Corresponding author.

E-MAIL viesturs.simanis@isrec.unil.ch; FAX +41-21-652-6933.
}

found at the growing ends of the cell, and, after the onset of mitosis, it relocates to form an equatorial ring whose position anticipates the site of septum formation (Marks and Hyams 1985; for review, see Robinow and Hyams 1989). At the end of mitosis, when the daughter nuclei are well separated and the spindle begins to break down, the septum grows inward from the cell cortex. Secondary septa are formed on either side of the primary septum, which subsequently is dissolved to effect cell separation. F-actin is then relocated to the old (preexisting) end of the cell from which growth resumes.

Some of the proteins that control the onset of septum formation and cytokinesis in fission yeast have been identified. The products of the $c d c 3, c d c 4, c d c 8, c d c 12$, $c d c 15$, and rng2 genes are required for actin rearrangement and/or to stabilize the actin ring (Nurse et al. 1976; Balasubramanian et al. 1992, 1994; Fankhauser et al. 1995; McCollum et al. 1995; Chang et al. 1996). A functional spindle is not required to specify the position of the actin ring, as it is already present and properly located in a $\beta$-tubulin mutant, which is arrested in prometaphase and lacks a mitotic spindle (Chang et al. 1996; for review, see Chang and Nurse 1996). Immunofluorescence studies have shown that the products of the $d m f 1, c d c 3, c d c 4, c d c 8$, and $c d c 15$ genes are associated with the medial ring (Balasubramanian et al. 1992, 1994; Fankhauser et al. 1995; McCollum et al. 1995; Sohrmann et al. 1996). The dmf1 protein is implicated in assuring 
correct positioning of the medial ring. Mutants of the $\mathrm{dmf1/mid1}$ gene misplace the division septum at high frequency (Chang et al. 1996; Sohrmann et al. 1996).

At the end of mitosis, the Cdc7p kinase and the activities of $\mathrm{Cdc} 11 \mathrm{p}$ and $\mathrm{Cdc} 14 \mathrm{p}$ are required for septation (Nurse et al. 1976; Fankhauser and Simanis 1993, 1994). The plo1 kinase appears to be required for both actin ring formation and septation, and can induce septum formation from $G_{1}$ and $G_{2}$ if expressed at a very high level (Ohkura et al. 1995). Once septation has been initiated, the products of the $c d c 16$ and byr 4 genes are implicated in limiting the cell to making a single septum per cell cycle (Minet et al. 1979; Song et al. 1996). Increased expression of byr4 blocks septation, suggesting that it is a dose-dependent inhibitor of septum formation (Song et al. 1996). A cdc16 mutant is unable to arrest in mitosis if spindle assembly is compromised (Fankhauser et al. 1993), and a null allele of byr4 displays mitotic abnormalities (Song et al. 1996). Byr4p is modified in mitotically arrested cells. This does not occur in a $c d c 16 \mathrm{mu}-$ tant, suggesting the Byr4p modification depends on Cdc16p activity (Song et al. 1996).

G-protein-regulated signal transduction pathways are implicated in control of the cytoskeleton, cell morphology, and cytokinesis in all eukaryotes (for review, see Hall 1994; Block and Wittinghofer 1995; Ridley 1995). A rho-related GTPase is required for cytokinesis in Dictyostelium (Larochelle et al. 1996), and inhibition of rho family GTPases can prevent formation of the cleavage furrow and disrupt contractile ring function in sand dollar embryos (Mabuchi et al. 1993). In Saccharomyces cerevisiae, CDC42, RHO1, RHO3, and RHO4 are all implicated in the development of cell polarity, asymmetric assembly of the actin cytoskeleton, and bud emergence (for review, see Ridley 1995).

In $S$. pombe, ras 1 controls both mating and morphogenesis, but is not essential for septum formation or viability (for review, see Hughes 1995). The $S$. pombe $c d c 42$ gene is essential for viability, and is required to establish proper polarity of the actin cytoskeleton and to control polarized cell growth. Dominant mutants induce an abnormal morphology, but do not promote septum formation (Miller and Johnson 1994). Cdc42p interacts with the $\operatorname{shk} 1^{+} / \mathrm{pak}^{+}$kinase, through which it signals to control morphology and mating (Chang et al. 1994; Marcus et al. 1995; Ottilie et al. 1995). Two other rho family G-proteins have been isolated from S. pombe (Nakano and Mabuchi 1995). One of these, Rholp, is involved in morphogenesis, and is required to activate the 1-3 $\beta-\mathrm{D}$ glucan synthase (Arellano et al. 1996).

Our previous studies of the $c d c 7$ gene suggested that the Cdc7p protein kinase is an important element in regulating the onset of septum formation, and therefore, could be a target of the coordination systems integrating mitosis and cytokinesis (Fankhauser and Simanis 1994). We have screened for proteins that interact with Cdc $7 p$, and have identified a GTPase of the Ras superfamily that acts as a dosage-dependent inducer of septation. It is likely that activation of Spg1p is the rate-limiting step in the initiation of septum formation.

\section{Results \\ Cloning of the spgl gene and isolation of spgl mutants}

During our study of the $c d c 7$ gene (Fankhauser and Simanis 1994), we observed that increased expression of active kinase caused multiple rounds of septum formation without cell division. In contrast, increased expression of the catalytically inactive $c d c 7(\mathrm{~K} 38 \mathrm{R})$ arrested cell division by blocking formation of the division septum. This result suggested to us that the ectopically expressed $\mathrm{Cdc} 7 \mathrm{p}(\mathrm{K} 38 \mathrm{R})$ was titrating a factor essential for septum formation away from the endogenous wild-type Cdc7p. To identify this protein, we isolated multicopy suppressors of the dominant negative $\mathrm{Cdc} 7 \mathrm{p}(\mathrm{K} 38 \mathrm{R})$ overexpression. A $S$. pombe strain containing the $c d c 7-24$ mutation and a single integrated copy of the $c d c 7(\mathrm{~K} 38 \mathrm{R})$ gene expressed from the nmt1 promoter was constructed (SP1684; see Materials and Methods). The cdc7-24 allele is partially defective at $25^{\circ} \mathrm{C}$ (Fankhauser and Simanis 1994), which renders cells more sensitive to increased levels of $\mathrm{Cdc} 7 \mathrm{p}(\mathrm{K} 38 \mathrm{R})$. After induction of the $n m t 1$ promoter at $25^{\circ} \mathrm{C}$, division ceases and cells become long and multinucleate. This strain was transformed with a multicopy $S$. pombe genomic DNA library and colonies were allowed to form at $25^{\circ} \mathrm{C}$ on thiamine-containing media. Replicas were made onto media without thiamine at $25^{\circ} \mathrm{C}$ to induce expression, and nine different plasmids were recovered from colonies that formed in the absence of thiamine. One of these, containing a $3.8-\mathrm{kb}$ insert, was chosen for further study. The insert hybridized to two transcripts of $\sim 1.3$ and $7 \mathrm{~kb}$ on Northern blots. Fragments hybridizing to the smaller message were shown to be responsible for the rescue of SP1684. This region was sequenced and the gene it encodes was named spg1 (septum-promoting GTPase), based on our studies of its role in septum formation (see below). Analysis of the other plasmids that rescued SP1684 indicated that all of them contained the spg1 gene. spg 1 mRNA and Spglp levels do not vary significantly during the cell cycle (data not shown), therefore neither transcriptional regulation, nor periodic degradation play an important role in regulating Spglp activity.

The spg1 gene was also cloned independently as a multicopy suppressor of $c d c 11-136$ (S. Schmidt and V. Simanis, unpubl.). Heat-sensitive alleles of spg1 were obtained in a screen for mutants that diploidize after a brief heat treatment (Hayles et al. 1994). The spgl gene encodes a small GTPase that is
essential for septum formation

Analysis of the spg1 genomic DNA sequence indicated the presence of four introns, whose presence was confirmed by sequencing of cDNAs isolated from a wildtype $S$. pombe cDNA library (Kelly et al. 1993). The sequence has been submitted to the EMBL database under the accession number Y12314. The spg1 gene encodes a 198-amino-acid protein of predicted molecular mass 
22,543. Database comparisons indicate that it is a small GTPase of the Ras superfamily. It is most closely related to Tem 1p of S. cerevisiae (Shirayama et al. 1994a). Spglp is $57 \%$ identical with Tem $1 \mathrm{p}$ and $17 \%$ identical with $\mathrm{N}-\mathrm{Ras}$. If conservative substitutions are considered, these figures increase to $68 \%$ and $28 \%$, respectively. The protein sequence, and a comparison with Tem lp and human N-Ras, is shown in Figure 1A. Expression of the $S$. cerevisiae TEM1 gene will not rescue the heat-sensitive mutant spg1-B8 (data not shown).

The evolutionary relationship of Spglp to other members of the superfamily of small G-proteins has been studied by molecular phylogeny analysis. The neighborjoining dendrogram shown in Figure $1 \mathrm{~B}$ indicates that Spglp and Tem $1 \mathrm{p}$ do not belong to any of the established G-protein subfamilies, but rather form a new family. Overall, they show highest sequence similarity to members of the Rab family. However, several invariant residues defining this subfamily are absent in Spglp and Temlp, most notably including the carboxy-terminal CAAX prenylation motif. Thus, it is unlikely that Spglp will be associated with cell membranes by lipid anchoring.

A null allele was created in a diploid by replacing part of the spg1 gene with the $u r a 4^{+}$gene (Fig. 1C). Replacement of one copy was verified by Southern blotting (Fig. 2B) and 30 tetrads were dissected. Only the two ura ${ }^{-}$ spores in each tetrad gave rise to colonies, demonstrating that the spg1 gene is essential for cell proliferation. Germination in liquid culture showed that spores carrying the spg1::ura4 $4^{+}$allele germinate, and grow, but are unable to divide. Multiple rounds of nuclear division occur in the absence of cell division, producing an elongated multinucleate cell. Because TEM1 has been implicated in exit from mitosis (Shirayama et al. 1994a), we examined whether mitosis was normal in these cells. Staining of cells with TAT-1 antibody demonstrated that apparently normal spindle and interphase microtubule configurations were present (Fig. 2A; Hagan and Hyams 1988). No increase in the number of anaphase cells was seen, compared to a wild-type population, suggesting that these cells do not have a defect at the end of mitosis.
A

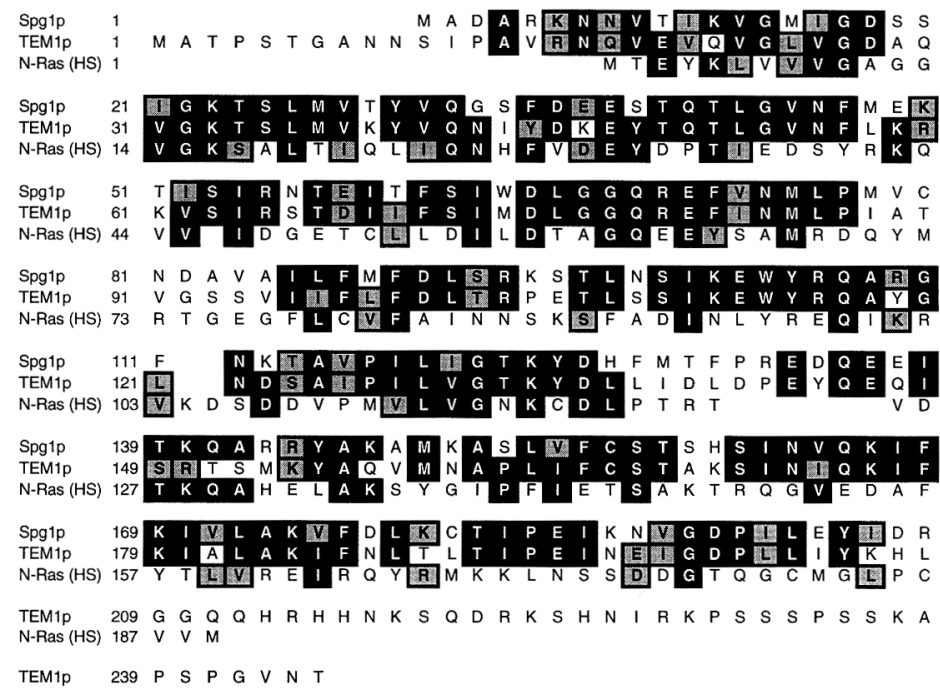

B
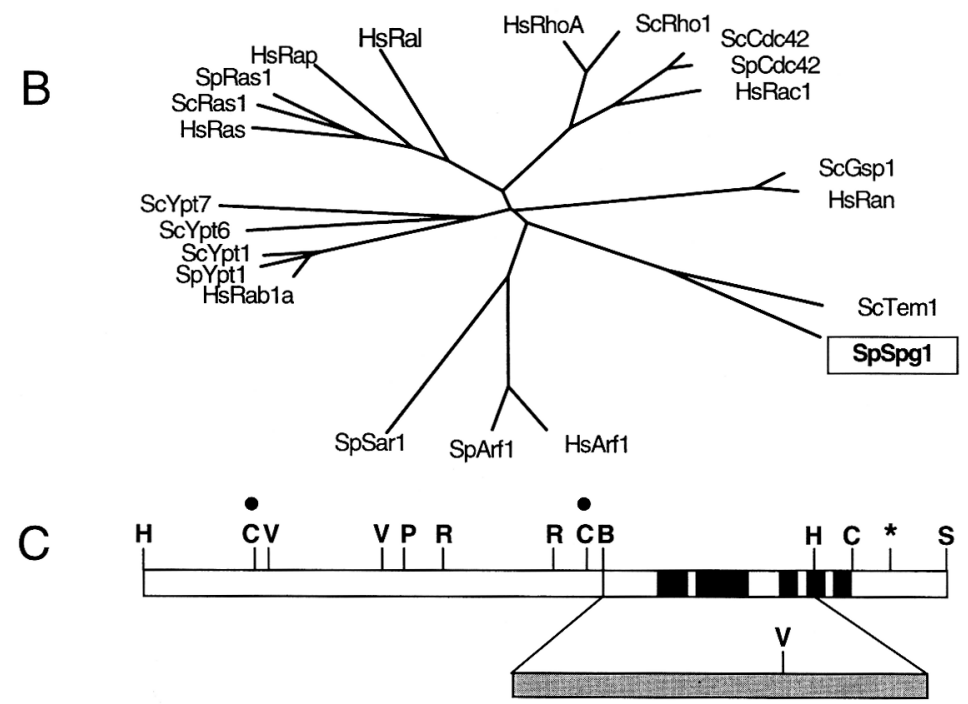

Figure 1. The spg1 gene encodes a GTPase of the Ras superfamily. (A) Sequence comparison of Spg1p, Tem lp, and N-Ras. The sequences have been aligned by eye to maximize homology, introducing gaps where required. Residues identical in two or three of the proteins are shown on a black background. The following amino acid substitutions were considered to be conservative, and are shown on a gray background: $K / R, I / L / V, N / Q, E / D, S / T, Y / F$. (B) Phylogenetic analysis using the neighbor-joining algorithm (Saitou and Nei 1987) was performed to analyze the evolutionary relatedness of Spglp to a representative subset of small GTPases of the Ras superfamily. (Hs) Human; (Sp) Schizosaccharomyces pombe; (Sc) Saccharomyces cerevisiae. $(C)$ Representation of the spg1 locus. A selected number of restriction enzyme cleavage sites are shown. The black bars represent the position of the five exons of the spg1 gene. The BgIII-HindIII fragment of the spg1 gene replaced by the $u r a 4^{+}$gene (shaded bar) to make the null allele is also shown. The black dots indicate the ClaI fragment used to probe the Southern blot shown in Fig. 2B. (B) BgIII; (C) ClaI; (H) HindIII; (P) PstI; (R) EcoRI; (S) Sau3A; (V) EcoRV. The asterisk represents a $P_{s t} \mathrm{I}$ site, not present in the genome, that is located in the pURL18 polylinker, adjacent to the Sall site used in construction of the library. This site was used to excise the linear fragment used for construction of the null allele. 
A

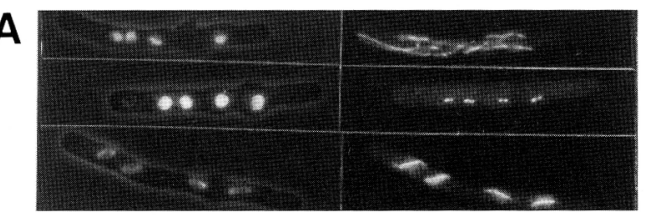
DAPI/Phase
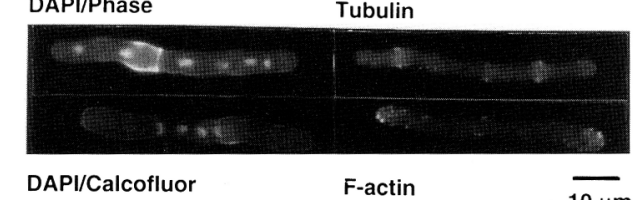

B

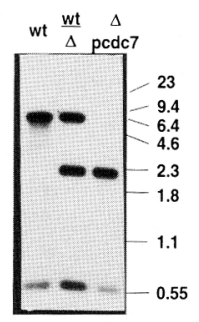

F-actin

C

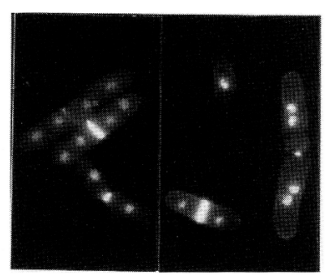

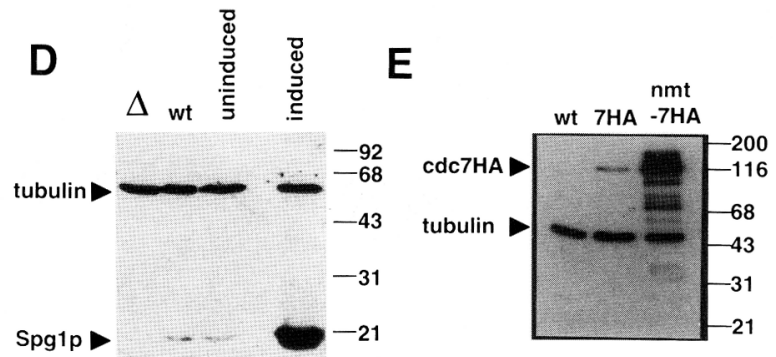
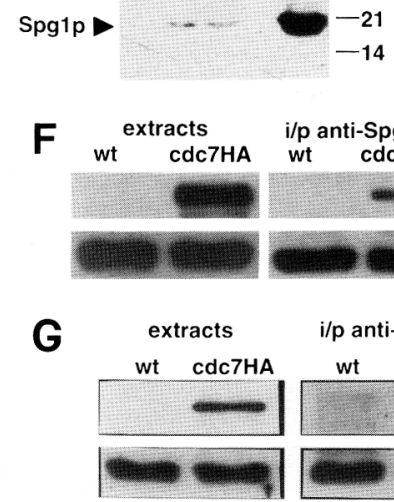

i/p anti-Spg1p i/p anti-HA
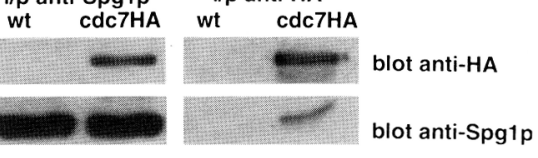

$i / p$ anti-Spg1p

wt cdc7HA

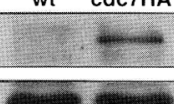

blot anti-HA blot anti-Spg1p

Figure 2. The spg1 gene is essential, but the null allele can be suppressed by increased expression of Cdc7p, with which Spg1p coimmunoprecipitates. $\{A \mid$ Spores prepared from the diploid SP1815 were grown in minimal medium supplemented with adenine and leucine, therefore only those inheriting the null allele could germinate. After $24 \mathrm{hr}$ at $25^{\circ} \mathrm{C}$, cells were fixed as described in Materials and Methods and stained to examine either the actin or tubulin cytoskeleton. (B) DNA was extracted from SP0560 (left lane), SP1815 (middle lane) and SP1930 (right lane). The DNA was digested and probed as described in Materials and Methods. Note the presence of an additional band in the diploid heterozygous for the null allele (middle lane), and the absence of the band corresponding to the wild-type allele in the right lane. $(C)$ Cells of strain SP1930 were grown to exponential phase in minimal medium supplemented with adenine, fixed with ethanol, and stained with DAPI and Calcofluor. Note that in contrast to the null allele $(A)$, binucleate septated cells are present. $(D)$ A Western blot of total protein from SP1930 $(\Delta), \mathrm{SP0001}(\mathrm{wt})$, and SP1805, either uninduced or induced for $16 \mathrm{hr}$ at $25^{\circ} \mathrm{C}$, was probed with affinity purified antibody to Spglp and TAT-1 as loading control. (E) A Western blot of total protein extracted from SP0001 (wt), SP1724 (7HA), or SP0007/7 (induced) was probed with the 12CA5 monoclonal antibody. TAT-1 was used as a loading control. $(F)$ Immunoprecipitates were prepared from proteins extracted from induced SP1805 or SP1805/7 cells, using either 12CA5 (anti-HA) or affinity-purified anti-Spglp antibody. After gel electrophoresis, Western blots of the immunoprecipitated proteins were probed with either 12CA5 (anti-HA) or affinity-purified anti-Spglp antibody. (G) Immunoprecipitates were prepared from protein extracts of wild-type cells (SP0001) or $c d c 7 H A$ cells (SP1724) using affinity-purified anti-Spg1p antibody. After gel electrophoresis, Western blots of the immunoprecipitated proteins were probed with either 12CA5 (anti-HA) or affinity-purified anti-Spglp antibody.

To investigate whether the failure to make a septum arises from inability to form an actin ring, or a defect in a later event, the actin rearrangements in both $s p g 1-B 8$ cells (data not shown) and germinating spg1::ura $4^{+}$ spores were examined by staining with rhodamine-conjugated phalloidin. Cells formed F-actin rings at mitosis (Fig. 2A), indicating that the block to septum formation occurs after actin ring formation. This is similar to the phenotypes of $c d c 7, c d c 11$, and $c d c 14$ mutants, which form an actin ring, but not a division septum (Fankhauser et al. 1995).

\section{Increased expression of the Cdc7p kinase rescues a null allele of spg1}

Because spg1 was isolated as a suppressor of a mutant $\mathrm{Cdc} 7 \mathrm{p}$ kinase, we tested whether increased dosage of $c d c 7$ could rescue mutations in spg1. We found that multicopy $c d c 7$ [either expressed under its own promoter, or uninduced from the modified $n m t 1$ promoter in pREP41 (Basi et al. 1993)], would rescue the spg1-B8 mutant at $36^{\circ} \mathrm{C}$ (not shown). Therefore, we tested whether increased expression of $c d c 7$ could also rescue the spg1::ura $4^{+}$allele. The diploid heterozygous for the null allele (SP1815) was transformed to leucine prototrophy with pREP41-cdc7, and spores were prepared. Colonies were obtained after plating spores on media selective for both the plasmid (leucine) and the null allele (uracil). Southern blotting demonstrated that these cells lacked the wild-type allele of $s p g 1$ (Fig. 2B). No leucine auxotrophes were isolated after growth in nonselective conditions, showing that the ability to divide depends on increased $c d c 7$ expression, rather than a spontaneous chromosomal suppressor mutation. Although cells could form a colony, many multinucleate cells were observed, indicating that $c d c 7$ overexpression does not compensate completely for the spg1 null allele (Fig. 2C).

\section{Cdc7p and Spg1p interact physically}

To investigate whether Cdc7p and Spglp interact, reagents were generated to identify Cdc7p and Spglp. A 
polyclonal antibody recognizing Spglp was raised by immunizing rabbits. The specificity of the anti-Spglp antibodies was demonstrated by Western blotting of protein extracts prepared from the null mutant rescued by $c d c 7$ overexpression (SP1930), wild-type cells (SP0007), or SP1805 cells, which carry a single integrated copy of the spg1 gene, expressed from the $n m t 1$ promoter. A protein of $23 \mathrm{kD}$ is seen in wild-type and uninduced SP1805 cell extracts. Its abundance increases with induction, and it is absent from extracts of cells bearing the null allele, demonstrating that the protein recognized is Spg1p (Fig. 2D).

The chromosomal copy of the $c d c 7$ gene was replaced with a copy tagged at its carboxyl terminus with the 12CA5 influenza virus hemagglutinin (HA) epitope (Chen et al. 1993). These cells (hereafter referred to as cdc7-HA) were indistinguishable from wild type (not shown). Western blots of protein extracts prepared from the $c d c 7-$ HA strain showed that the monoclonal antibody recognizing the epitope reacts with a band of the expected size for Cdc7-HAp (120 kD) in $c d c 7-\mathrm{HA}$ proteins extracts. The abundance of this protein increases in cells expressing $c d c 7-$ HA from a multicopy plasmid, and it is absent from wild-type cells (Fig. 2E).

Immunoprecipitates using antibodies either against the HA tag or Spglp were prepared from protein extracts of SP1805/7 cells, in which expression of Cdc7-HAp and Spglp is increased. The two immunoprecipitates were then Western blotted to detect either Cdc7-HAp or Spg1p. Antibodies to Spglp immunoprecipitated Cdc7HAp, and vice versa (Fig. 2F). However, from the strength of the signals, it is clear that only a fraction of the Cdc7p and Spglp in the extract are associated. When a similar experiment was performed on wild-type or $c d c 7-\mathrm{HA}$ protein extracts, in which $c d c 7$ and spg1 are not overexpressed, anti-Spglp antibodies immunoprecipitated Cdc7-HAp (Fig. 2G). However, immunoprecipitates prepared with the monoclonal antibody against the HA tag did not reproducibly contain $\mathrm{Spg} 1 \mathrm{p}$ (not shown). Because only a fraction of Spglp can be immunoprecipitated together with Cdc7-HAp, this may be attributable to a lack of sensitivity in the Western blots.

To confirm the interaction of Spglp and Cdc7p by an independent method, the two genes were used in a twohybrid assay (Durfee et al. 1993). Introduction of either $c d c 7$ or spg1 into $S$. cerevisiae did not stimulate $\beta$-galactosidase expression, whereas the simultaneous presence of both $c d c 7$ and spg1 caused a $>100$-fold stimulation in $\beta$-galactosidase activity (Table 1). Plating of cells on Xgal-containing media gave rise to blue colonies only if $c d c 7$ and spg1 were coexpressed (not shown).

\section{Increased expression of Spg1p induces septum formation}

Because increased expression of $c d c 7$ deregulates septum formation (Fankhauser and Simanis 1994), and Cdc7p interacts with Spglp, we examined the effect of increased expression of spg1. A single copy of $\operatorname{spg} 1$, expressed from the thiamine-repressible $n m t 1$ promoter, was integrated
Table 1. Interactions between Cdc7p and Spg1p in the two-hybrid system

\begin{tabular}{llc}
\hline \multicolumn{2}{c}{ Plasmids } & Miller units \\
\hline pGAD10 & pBTM116 & 1.3 \\
pGAD10-cdc7 & pBTM116 & 1.8 \\
pGAD10 & pBTM116-spg1 & 1.8 \\
pGAD10 & pBTM116-spg1 (T42A) & 2.9 \\
pGAD10-cdc7 & pBTM116-spg1 & 193 \\
pGAD10-cdc7 & pBTM116-spg1 (T42A) & 28 \\
\hline
\end{tabular}

into the leu1 gene, using the INT5 vector (described in Fankhauser and Simanis 1994). The promoter is induced $-13 \mathrm{hr}$ after shift to thiamine-free medium (about three generations at $\left.25^{\circ} \mathrm{C}\right)$. One generation later $(4 \mathrm{hr})$, cell division slowed down dramatically (Fig. 3A). The uninduced culture, in which the level of Spglp produced is very low (Fig. 2D), showed a normal generation time. Examination of the cells overexpressing Spglp at intervals after induction showed that the number of septated cells in the population increased (Figs. 3B and 4D), reaching $100 \%$ after 5 generations $(20 \mathrm{hr})$. However, cell cleavage did not occur, and at later times, multiseptate cells accumulated, indicating that septum formation is deregulated by continued expression of Spglp. The appearance of multiseptate cells occurred approximately one generation $(4 \mathrm{hr})$ after the appearance of the first septated cells. The septated cells produced after induction contained either one or two nuclei (Fig. 4D,F), suggesting that septum formation was no longer dependent on the initiation of mitosis; subsequent experiments verified this hypothesis (see below).

Staining of cells with rhodamine-conjugated phalloidin showed that F-actin formed a ring at the site of septation. When multiple septa had been formed, the actin ring was associated with the most recently formed septum (Fig. 3C). Staining with antibodies against Cdc15p showed that it also formed a ring in cells overproducing Spg1p (Fig. 3C). Staining of microtubules showed arrays typical of interphase cells. In cells with a septum, the array emanated from the center of the cell (Fig. 3C). To date, we have not been able to determine whether this is a postanaphase array (Hagan and Hyams 1988), or an interphase array that has been "pinched" by the growing septum. Increased expression of the TEM1 gene does not induce septum formation in wild-type $S$. pombe cells (data not shown).

\section{The effect of increased production of Spg1p mutants}

The effect of mutations on the signaling activity of Raslike G-proteins is well documented (Bourne et al. 1991). Therefore, a number of mutants of Spglp were generated and tested for their effects on septum formation. The Q69L mutant (equivalent to Q61L in N-Ras) is defective in GTP hydrolysis and therefore, signals constitutively, whereas the D125A mutant (equivalent to D119A in NRas) has a high spontaneous nucleotide exchange rate 

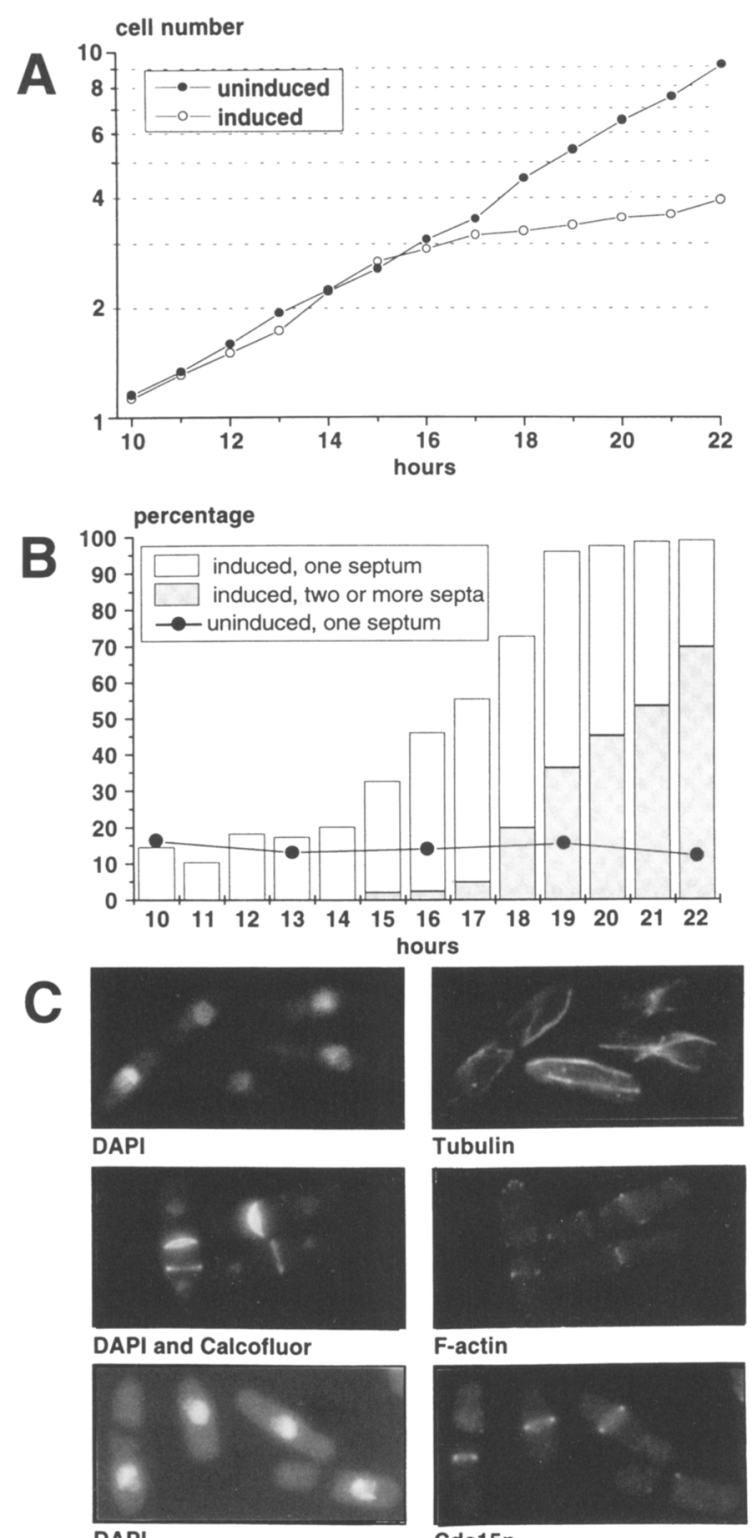

\section{Tubulin}

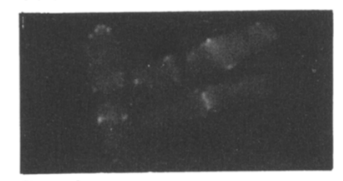

F-actin

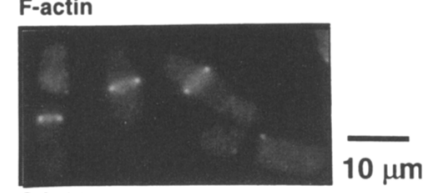

DAPI

Cdc15p

Figure 3. Increased expression of Spglp is toxic and promotes septum formation. (A) Strain SP1805 was grown to mid-exponential phase and expression of Spglp was induced by growth in minimal medium without thiamine at $25^{\circ} \mathrm{C}$. Under these conditions, the promoter is induced after $\sim 13 \mathrm{hr}$. Cell number was determined using a Coulter counter. Uninduced cells served as a control. $(B)$ Cells from the experiment described in $A$ were fixed and stained with DAPI and Calcofluor. The bars indicate the total percentage of cells with septa after induction. The shaded bars indicate the percentage of cells with more than one septum. The line indicates the number of septated cells in the uninduced control. $(C)$ Cells from the experiment described in $A$ were fixed and stained with the indicated reagents, as described in Materials and Methods, $19 \mathrm{hr}$ after induction.

(Sigal et al. 1986). In Ras, both these mutations are oncogenic in NIH-3T3 cell transformation assays (Sigal et al. 1986). The T24N mutant (equivalent to $S 17 \mathrm{~N}$ in $\mathrm{N}$ -

Ras) is predicted to titrate out the guanine nucleotide exchange factor (GEF), and thus to act as a dominant negative by inhibiting the ability of the endogenous Spglp to signal. The T42A mutation (equivalent to T35A in N-Ras) lies in the effector domain (Wittinghofer and Valencia 1995), and should prevent efficient interaction of Spglp with its targets.

The mutants were expressed in wild-type cells, from the attenuated nmt1 promoter contained in pREP81 (Basi et al. 1993), and the percentage of septated cells was determined at intervals after induction in exponentially growing cultures. Increased septation resulting from expression of wild-type Spglp was observed after $18 \mathrm{hr}$ at $25^{\circ} \mathrm{C}$, and reached a value of $50 \%$ septation after $-20 \mathrm{hr}$ (Fig. 4A; note that the later induction of septation com-

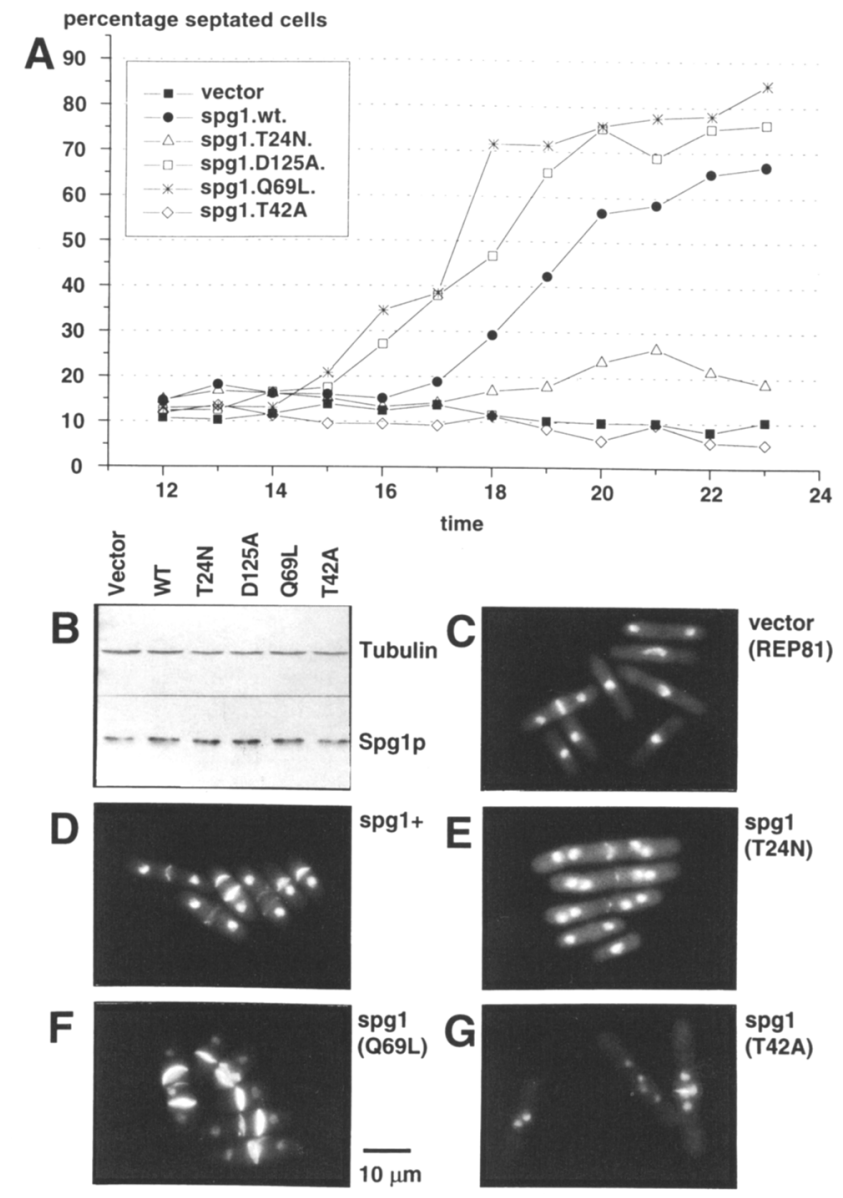

Figure 4. The effects of overproduction of spg1 mutants suggest that the GTP bound form induces septum formation. $(A)$ Wild-type (SP0007) cells were transformed with REP81 expressing either $s p g 1^{+}$or the indicated spg1 mutants. Expression was induced at $25^{\circ} \mathrm{C}$, and the percentage of septated cells was determined at intervals thereafter. $(B)$ Protein extracts were prepared from cells transformed with REP81 expressing the indicated spg1 mutant, spg $1^{+}$, or an empty vector, $20 \mathrm{hr}$ after induction at $25^{\circ} \mathrm{C}$. Western blots were probed with affinity purified antiSpglp antiserum and TAT-1 as loading control. $(C-G)$ Photographs of the cells described in $A$ and $B, 20 \mathrm{hr}$ after induction. Cells were stained with DAPI and Calcofluor. 
pared with Fig. 3A results from the use of a much weaker promoter in this experiment). At this time, Western blots of cell extracts showed that the level of wild-type Spglp and mutant Spg1p produced were similar, and increased less than threefold compared to the endogenous level in the vector control (Fig. 4B). The activated mutants Q69L and D125A both induced septation earlier than wild-type Spg1p; $50 \%$ of cells were septated after 17 and $18 \mathrm{hr}$, respectively. Examination of the cells $18 \mathrm{hr}$ after induction indicated that the Q69L mutant contained more multiseptate cells than wild type (Fig. 4F). A similar result was observed after induction of D125A (not shown). In contrast, the $\mathrm{T} 24 \mathrm{~N}$ mutant produced only a transient increase in the number of septated cells, whereas the T42A mutant caused a small decrease. Many tetranucleate cells were present in both these cultures (Fig. 4E,G), indicating that septation had been inhibited by expression of the T42A and T24N mutants. The T42A effector domain mutant also interacted less strongly with Cdc7p in a two-hybrid assay (Table 1), suggesting that the signaling by Spg1p is mediated directly through Cdc7p. These data demonstrate that only a small increase in expression of Spglp is required to induce septation, and suggest strongly that the GTP-bound form of the protein is the biologically active one.

\section{Induction of Spg1p expression in synchronized cell populations}

To examine the effect of increasing the dosage upon the timing of septum formation in the cell cycle, Spg1p expression was induced in SP1805 cells. At intervals thereafter, part of the culture was subjected to centrifugal elutriation, and small unseptated cells were selected. In each synchronization (all from the same induced culture), the number of cells loaded and the flow rate used for elution were the same, ensuring that the size of the cells at the time of reinoculation into fresh medium was similar for all the cultures. The percentage of septated cells was determined at intervals thereafter. None of the cultures contained septated cells at the time of reinoculation (Fig. 5A). Uninduced control cells showed a peak of binucleate septated cells at the expected time, 210 min (Fig. 5B). No mononucleate septated cells were seen (Fig. 5D). In contrast, induction of $s p g 1$ before synchronization resulted in earlier onset of septation (Fig. 5D). The longer the time of induction, the more the initiation of septation was advanced. This was accompanied by the appearance of mononucleate cells with one or more septa (Fig. 5D) and by a decrease in the number of both mitotic (Fig. 5C) and "normal" binucleate septated cells

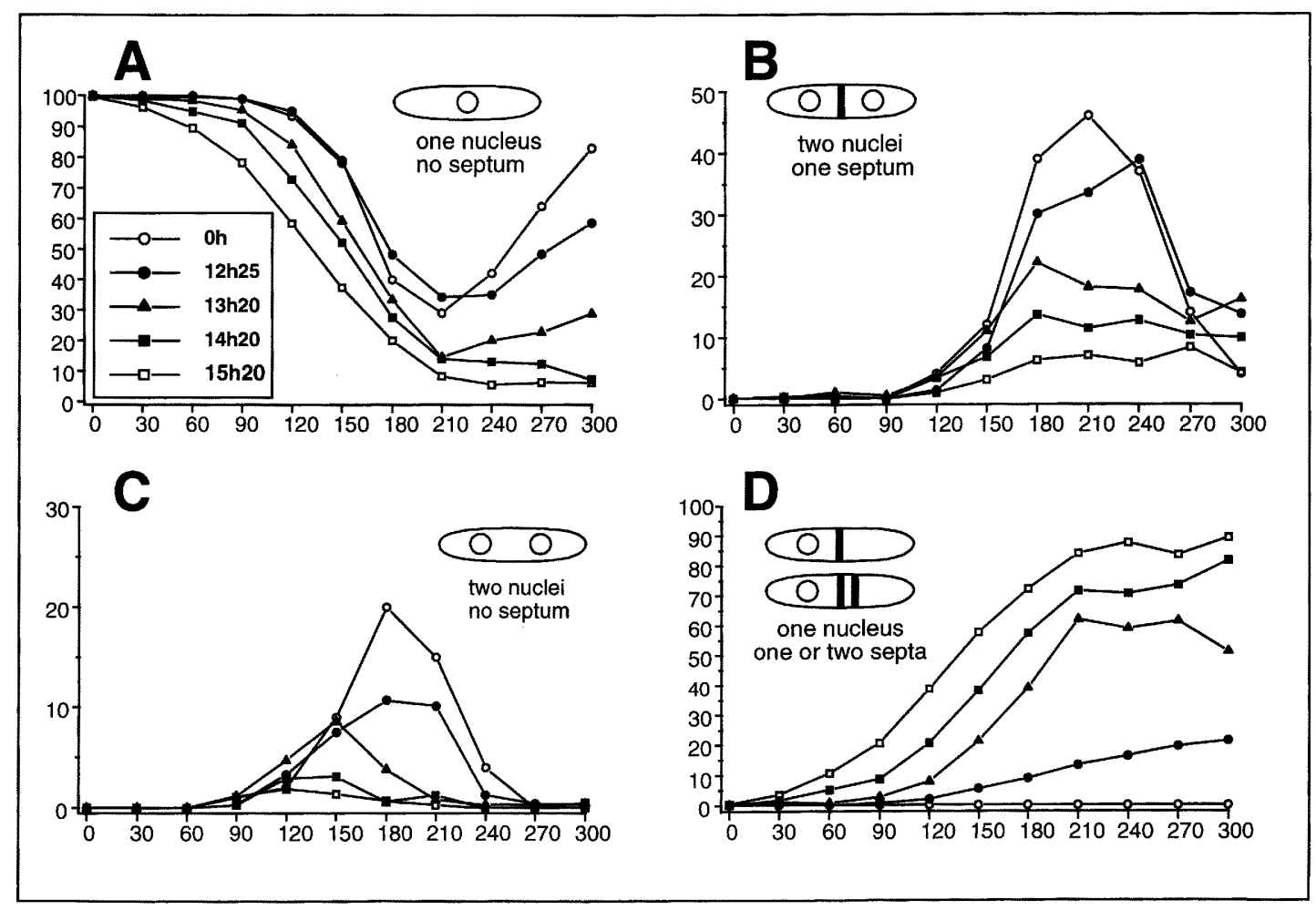

Figure 5. Spglp is a dosage-dependent inducer of septum formation. Expression of $\operatorname{spg} 1$ was induced in SP1805 cells at $25^{\circ} \mathrm{C}$ in minimal medium supplemented with leucine. Cells $\left(3 \times 10^{8}\right)$ were removed at intervals, and separated by centrifugal elutriation. The time indicated in the legend is the total time after induction, including the elutriation (which took $\sim 30$ min), before reinoculation. The $\mathrm{x}$-axis on each graph is the time in minutes after reinoculation at $25^{\circ} \mathrm{C}$. Cells were fixed and stained with DAPI and Calcofluor. $(A)$ nonseptated mononucleate cells, $(B)$ septated, binucleate cells, $(C)$ nonseptated binucleate cells, $(D)$ monoseptate, or multiseptate, mononucleate cells. 
(Fig. 5B). Fewer than $1 \%$ of nuclei were cut by the precociously induced septum (see Discussion section). These data demonstrate that Spglp is a dosage-dependent inducer of septation. Fluorescence-activated cell sorter (FACS) analysis of cells from the $15 \mathrm{~h} 20$ induction $6 \mathrm{hr}$ after reinoculation (when $>90 \%$ of cells have a septum) indicated that the arrested, septated cells had a $2 \mathrm{C}$ DNA content (data not shown).

\section{Increased expression of Spg1p induces septum} formation in both $G_{2}$ and pre-START-arrested cells

Normally, septum formation depends on entry into mitosis (Minet et al. 1979). To test whether septum formation induced by spg 1 required entry into mitosis, the single integrated copy of spg1 was crossed into $c d c 2-17$, a $c d c 2$ allele that arrests uniquely in $\mathrm{G}_{2}$ and shows very low protein kinase activity at the restrictive temperature (MacNeill et al. 1991; Fankhauser et al. 1995). Cells were induced for $10.5 \mathrm{hr}$ at $25^{\circ} \mathrm{C}$, synchronized by elutriation (30 min, giving a total of $11 \mathrm{hr}$ of induction), and the $\mathrm{G}_{2}$ cells reinoculated at $36^{\circ} \mathrm{C}$ for $3 \mathrm{hr}$. No septated cells were observed at the time of shift to $36^{\circ} \mathrm{C}$. An uninduced culture, subjected to an identical elutriation, served as control and arrested in $\mathrm{G}_{2}$ as elongated cells with a single nucleus; $<2 \%$ of cells had a septum (Fig. 6A). In contrast, in the induced culture, $58 \%$ of cells were septated, and all of these had a single nucleus (Fig. 6A). These data demonstrate that $\operatorname{spg} 1$ can induce septation in $\mathrm{G}_{2}$, without the requirement for $c d c 2$ kinase activity, and therefore, bypassing the normal dependency on entry into mitosis. Similar results were obtained after induction of Spglp in a cdc25-22 background (not shown).

Next, we tested whether spg1 could induce septum formation in a $c d c 10-V 50$ mutant, which is arrested in $\mathrm{G}_{1}$ before traverse of START. To ensure that cells had completed mitosis and arrested at the $c d c 10$ block point before induction of $\operatorname{spg} 1$, they were grown in thiaminefree medium for only $8 \mathrm{hr}$ at $25^{\circ} \mathrm{C}$ before elutriation, and were then allowed to divide once after reinoculation and shift to $36^{\circ} \mathrm{C}$ (Fig. 6B). This first division was normal in both the induced culture and the uninduced control (Fig. $6 \mathrm{C}, 180 \mathrm{~min}$ ), and a doubling of the cell number occurred after septation (not shown). Three hours later, the control cells had not septated, whereas the induced culture contained mononucleate septated cells (Fig. 6B,C, 360 min). FACS analysis demonstrated that both cultures remained arrested in $\mathrm{G}_{1}$ (not shown). Therefore, induction of spg1 can induce septum formation in a pre-START, $\mathrm{G}_{1}$-arrested cell. Septa were also produced upon induction of spg 1 in cells arrested in S-phase by addition of hydroxyurea (not shown).

Mononucleate septated cells could arise either because the cell compartment produced after septation is too small to permit mitosis to occur, or because elevated expression of spg1 inhibits mitosis. To distinguish these possibilities, the integrated $n m t 1-s p g 1$ expression cassette was crossed into a wee $1-50$ mutant. At $36^{\circ} \mathrm{C}$, these cells enter mitosis at a reduced size, and as a consequence, are smaller at division, whereas at $25^{\circ} \mathrm{C}$ mitosis
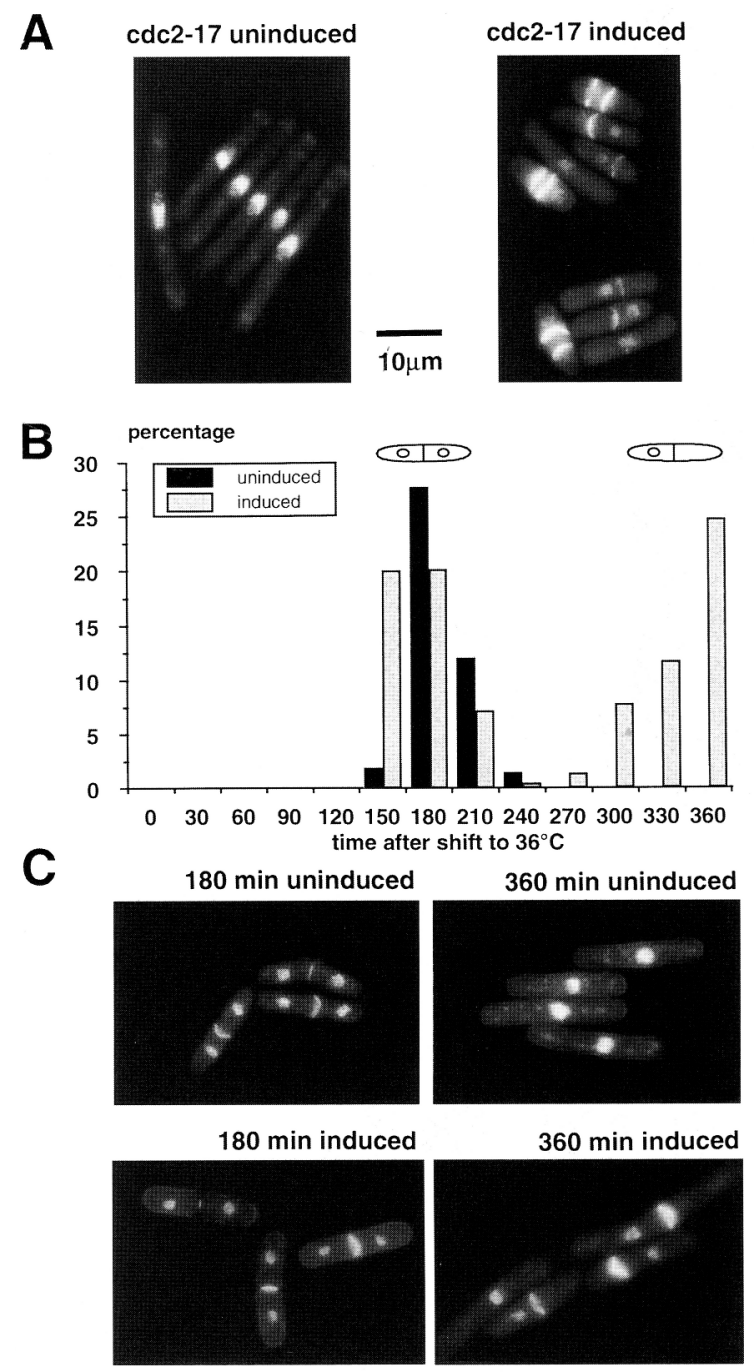

Figure 6. Increased expression of Spg1 1 induces septum formation in $\mathrm{G}_{2}$-arrested cells and in pre-START arrested cells. $(A)$ SP1887 cells were induced to express Spglp for a total of $13 \mathrm{hr}$ (including elutriation), and small nonseptated cells were selected by elutriation. They were inoculated at $36^{\circ} \mathrm{C}$ for $3 \mathrm{hr}$, fixed, and stained with DAPI and Calcofluor. The same strain, uninduced, but otherwise subjected to an identical protocol, served as control. (Left) Uninduced cells; (right) induced cells. (B) SP2194 cells were induced as in $A$, except that the total time before reinoculation was $8 \mathrm{hr}$. Cells were then incubated for 30 min at $25^{\circ} \mathrm{C}$ to ensure that START had been completed, and then shifted to $36^{\circ} \mathrm{C}$. Cells were fixed and stained with DAPI and Calcofluor to determine the number of septated cells at the indicated times. Note that the first division was normal, and that septa appeared subsequent to the arrest only in the induced culture. $(C)$ Cells from the experiment described in $B$ were fixed and stained with DAPI and Calcofluor, 180 and 360 min after reinoculation, subsequent to elutriation.

and division occur at approximately wild-type size (Nurse 1975). Cells were synchronized by elutriation at $25^{\circ} \mathrm{C}$, after induction of $\operatorname{spg} 1$ expression for $14 \mathrm{hr}$ [to ensure that most septated cells would be mononucleate (see Fig. 5)]. Two hundred forty minutes after reinocula- 
tion at $25^{\circ} \mathrm{C},>80 \%$ of the cells contained one or more septa, and $<1 \%$ had two nuclei in the same compartment (Fig. 7A, graph). The culture was then shifted to $36^{\circ} \mathrm{C}$ to inactivate Weelp, which induced mitosis in many cells, producing binucleate cell compartments (Fig. 7A, inset). This demonstrates that increased expression of spg1 does not inhibit entry into mitosis, and suggests that mononucleate septated cells arise because the compartment produced after septum formation is too small to permit mitosis in a wee $1^{+}$background.

We also examined the dependence of septum formation induced by Spglp on proteins required for actin ring formation or septation. Disorganized septa were formed after induction of a single copy of $\operatorname{spg} 1$ at $36^{\circ} \mathrm{C}$ in $c d c 3-6$, $c d c 4-8, c d c 8-110$, and cdc12-112 mutants (not shown). No septa were seen after induction in a cdc15-140 mutant (not shown). This is similar to the phenotype produced after incubation of the single mutants at the non-
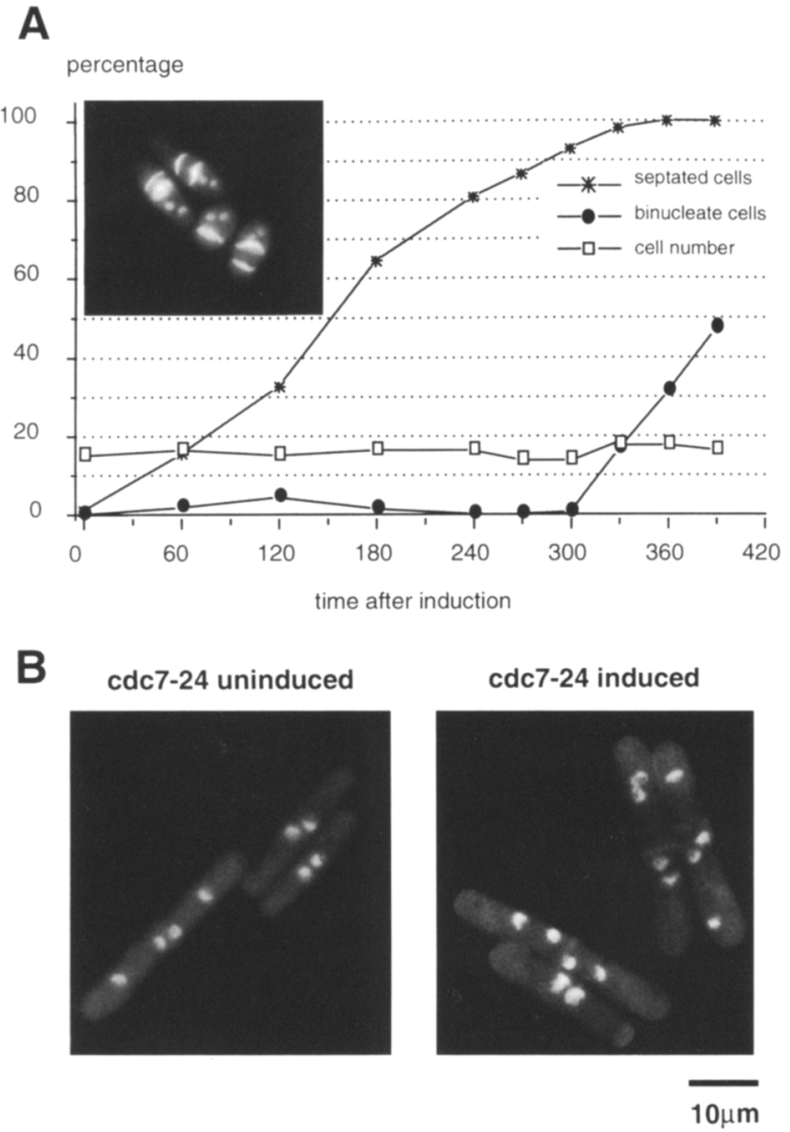

Figure 7. Induction of septum formation does not prevent subsequent entry into mitosis, and depends on Cdc7p kinase activity. (A) SP2216 cells were induced as described in Fig. 6A, except that the total time before reinoculation at $25^{\circ} \mathrm{C}$ was $14 \mathrm{hr}$. After $240 \mathrm{~min}$, the culture was transferred to $36^{\circ} \mathrm{C}$ to inactivate Weelp. Cells were fixed at intervals, and stained with DAPI and Calcofluor. The inset image shows cells $360 \mathrm{~min}$ after reinoculation $\left(120 \mathrm{~min}\right.$ after shift to $\left.36^{\circ} \mathrm{C}\right) .(B)$ SP1806 cells were treated as described in Fig. 6A. (Left) Uninduced cells; (right) induced cells. permissive temperature (Nurse et al. 1976). Thus, induction of a septum by increased expression of Spglp still requires the activity of proteins required for assembly of the actin ring.

Increased expression of Spg1p in $c d c 16-116$ at $36^{\circ} \mathrm{C}$ produced multiseptate cells, similar to the $c d c 16-116$ mutant at restrictive temperature (Minet et al. 1979; not shown). The uninduced "leak through" expression level of $s p g 1$ from the $n m t 1$ promoter on a multicopy plasmid in the presence of thiamine suppressed $c d c 11-136$ at the restrictive temperature. Cells become multiseptate with induction (not shown). No septum was induced in cdc14-118 after overexpression of Spg1p (not shown). Induction of spg1 did not induce septation in $c d c 7-24$ at the restrictive temperature (Fig. 7B), and increased expression of spg1 could not rescue a $c d c 7:: u r a 4^{+}$null allele (not shown). Therefore, the induction of septum formation by $s p g 1$ requires the activity of $\mathrm{Cdc} 7 \mathrm{p}$ kinase, with which it interacts.

\section{Genetic interactions of spg1 with other genes implicated in septum formation}

Double mutants between spg1-B8 and $d m f 1-6, c d c 3-6$, cdc4-8, cdc7-24, cdc7-A20, cdc8-110, cdc11-136, cdc12112, $c d c 14-118, c d c 15-140$, and $c d c 16-116$ were constructed by tetrad dissection. A summary of the growth of double mutants at different temperatures, for the instances where a genetic interaction was observed, is given in Table 2.

Double mutants of $\operatorname{spg} 1-B 8$ with either of the alleles of $c d c 7$ showed a markedly reduced restrictive temperature, consistent with them acting in the same pathway, and interacting physically. The double mutant cdc16116 spg $1-B 8$ was viable at $34^{\circ} \mathrm{C}$ and $36^{\circ} \mathrm{C}$, in contrast to either of the individual mutants. A severely reduced restrictive temperature was observed for the double mutant spg1-B8 cdc14-118, which formed colonies poorly, even at $19^{\circ} \mathrm{C}$. The mutant $c d c 11-136$ spg1-B8 also showed a reduced restrictive temperature. Taken together, these data suggest that these proteins may interact to regulate septum formation, and is addressed further in the Discussion.

Among the genes tested that are implicated in formation or positioning of the actin ring, a genetic interaction was observed only in the case of $c d c 15-140 \operatorname{spg} 1-B 8$, which showed a slight reduction of restrictive temperature. No additive effect was observed with $c d c 3-6, c d c 4$ $8, c d c 8-110, c d c 12-112$, or $d m f 1-6$.

\section{Discussion}

\section{Spg1p is a dosage-dependent inducer of} septum formation

The data presented in this paper establish that the product of the spg1 gene, a small GTPase of the Ras superfamily, is an essential dosage-dependent inducer of sep- 
Table 2. Genetic interactions of spg1 with other genes implicated in the control of septum formation

\begin{tabular}{lcccccc}
\hline & \multicolumn{6}{c}{ Temperature $^{\mathrm{a}}$} \\
\cline { 2 - 7 } Mutant & $19^{\circ} \mathrm{C}$ & $25^{\circ} \mathrm{C}$ & $29^{\circ} \mathrm{C}$ & $32^{\circ} \mathrm{C}$ & $34^{\circ} \mathrm{C}$ & $36^{\circ} \mathrm{C}$ \\
\hline spg1-B8 & ++ & + & $+/-$ & - & - & - \\
cdc7-24 & ++ & + & $+/-$ & - & - & - \\
cdc7-A20 & ++ & ++ & + & $+/-$ & - & - \\
cdc11-136 & ++ & ++ & + & + & - & - \\
cdc14-118 & ++ & + & + & $+/-$ & - & - \\
cdc15-140 & ++ & ++ & + & - & - & - \\
cdc16-116 & ++ & ++ & ++ & + & - & - \\
spg1-B8 cdc7-24 & + & $+/-$ & $+/-$ & - & - & - \\
spg1-B8 cdc7-A20 & ++ & + & - & - & - & - \\
spg1-B8 cdc11-136 & ++ & $+/-$ & - & - & - & - \\
spg1-B8 cdc14-118 & + & - & - & - & - & - \\
spg1-B8 cdc15-140 & ++ & ++ & - & - & - & - \\
spg1-B8 cdc16-116 & + & $+/-$ & $+/-$ & $+/-$ & + & + \\
\hline
\end{tabular}

Double mutants were created by tetrad dissection. Cells were grown in liquid culture, and dilutions were spotted onto YE medium at the indicated temperatures. To assess the numbers of dead cells, colonies were replica plated onto medium containing phloxin $\mathrm{B}$.

${ }^{a}(++)$ Good colony formation, similar to wild-type, most cells healthy (phloxin-pink); $(+)$ colony formation, but significant numbers of dead cells (phloxin-red); $(+|-|$ poor growth, small colonies, high percentage of dead cells; $(-)$ does not form colonies.

tum formation in fission yeast. Increased expression of Spglp induces septation at any stage of the cell cycle. $G_{2}$ cells that have formed a septum in response to elevated levels of Spg1p do not undergo DNA replication, but remain arrested with a $2 \mathrm{C}$ DNA content. Thus, precocious induction of septation does not place the cell in a postmitotic state. Consistent with this, they are able to enter mitosis after forming the division septum, if the size requirement for mitotic initiation is reduced. Therefore, a major conclusion of this work is that proper regulation of Spglp activity is important, not only for the initiation of septation at the end of mitosis, but also to prevent septum formation at inappropriate stages of the cell cycle.

Increased expression of Spglp induces all the events of septation that occur at the onset of mitosis, including the rearrangement of actin patches from the growing tips to the center of the cell. The septum is also often placed centrally when induced in wild-type cells, indicating that the signals required for correct positioning of the septum have also been provided. However, examination of heat sensitive and null mutants of spg1 shows that rearrangement of F-actin to form the medial ring does not require Spglp. It is possible that $\mathrm{Spglp}$ is functionally redundant with another GTPase for signaling the rearrangement of F-actin. Alternatively, the increased amount of Spglp may trigger a G-protein-controlled signaling cascade that regulates cell polarity and actin rearrangement, which is normally regulated by another GTPase. These possibilities will be examined in future studies.
The septa induced by increased expression of spg1 are not cleaved. This is also observed with overexpression of Cdc7p kinase (Fankhauser and Simanis 1994), plo1 kinase (Ohkura et al. 1995), or inactivation of either cdc16 (Minet et al. 1979) or byr4 (Song et al. 1996). This suggests that additional signals may be required to initiate cell cleavage after septum formation, and as long as the septation machinery is active, the signals are not given or ignored. Alternatively, the septa that are made may not be cleaved because they are defective.

The nucleus is very rarely cut in the mononucleate septated cells resulting from spg1 overexpression. The septum is most frequently placed in the middle of the cell, with the nucleus positioned in the center of one of the two halves of the cell, where it would have been had a normal mitosis been completed. A potential explanation for this can be envisioned as follows: Tubulin staining (Fig. 3C) indicated that the half-cells each contain an interphase-like basket of microtubules. If this resulted from pinching of a preexisting cytoplasmic array, then the nucleus, which is always found at the widest (middle) point of the array, would be pushed to the center of the new microtubule array in the half-cell it occupies. The same would apply if postanaphase arrays were created after septation. Alternatively, inducing septum formation may activate a postmitotic nuclear positioning mechanism that locates the nucleus in the half-cell. In this context, it is interesting to note that cut mutants (Hirano et al. 1986; Samejima et al. 1993) are arrested in metaphase or early anaphase of mitosis, when the cytoplasmic microtubule array has been replaced by the spindle. There is then no means by which the nucleus can be moved sideways as the septum is synthesized, unless it is pushed aside by the growing septum. Thus, a significant proportion of nuclei will be cut.

\section{What is the in vivo role of the interaction of Spg1p and $C d c 7 p$ ?}

Assays of Cdc7p kinase activity in extracts prepared from spg 1-B8 cells grown either at $25^{\circ} \mathrm{C}$ or $36^{\circ} \mathrm{C}$, indicate that $\mathrm{Cdc} 7 \mathrm{p}$ kinase activity is unimpaired in vitro by inactivation of Spglp (M. Sohrmann, S. Schmidt, I. Hagan, and V. Simanis, in prep.). One role of Ras superfamily GTPases is to direct proteins to the correct subcellular location; for example, the targeting of Raf to the cell membrane by Ras (Leevers et al. 1994), and Cdc42p targeting Ste20p to the bud tip in $S$. cerevisiae (Peter et al. 1996). We are attempting to localize Cdc7p and Spglp to determine whether Spglp function is required to localize Cdc7p correctly. The interaction of Spglp with Cdc $7 p$ may serve to direct it to its substrates, or may be a prerequisite for additional modifications to activate it in vivo. Future experiments will explore these possibilities.

\section{Similarity of Tem1p and Spg1p proteins}

Database comparisons indicated that Spglp is most similar to $S$. cerevisiae Tem $1 \mathrm{p}$ (this study), and that Cdc7p is 
most similar to S. cerevisiae Cdc15p (Fankhauser and Simanis 1994). The S. cerevisiae TEM1 and CDC15 genes are implicated, together with LTE1, CDC20, $D B F 2, C D C 14$, and $C D C 5$, in controlling exit from mitosis (Kitada et al. 1993; Surana et al. 1993; Shirayama et al. 1994a,b). There are interesting similarities in the interactions observed among the $S$. cerevisiae genes and those we have detected in $S$. pombe. For example, increased expression, or an activated allele, of $C D C 15$ will rescue a null allele of TEM1 (Shirayama et al. 1994a), and overexpression of $c d c 7$ will rescue $\operatorname{spg} 1:: \mathrm{urat}^{+}$(see Results section). However, expression of Temlp in $S$. pombe cannot substitute for Spglp and does not induce septum formation. It is not known whether $C D C 15$ will rescue mutations in $c d c 7$, although high-level expression of the $S$. pombe $c d c 7$ gene gives weak rescue of a $S$. cerevisiae cdc15-1 mutant (Fankhauser and Simanis 1994). Therefore, despite the structural similarities, the degree to which the genes from one yeast are able to substitute individually for their counterparts in the other is limited, at best. The null and conditional mutant phenotypes of $c d c 7$ and spg1 indicate clearly that they play no essential role in the termination of mitosis, but are required for the onset of septum formation. It is possible that the signal transduction pathway involving these proteins is an ancient one, in evolutionary terms, and has been adapted to control different events in $S$. pombe and $S$. cerevisiae.

\section{What are the regulators of Spg1p?}

Because increased expression, or constitutively activated mutants, of spg1 deregulate septum formation, mutants that produce a similar phenotype may identify regulators of Spglp. Ras superfamily GTPase signaling is regulated by the activity of GTPase-activating (GAP) proteins, which stimulate the rate of GTP hydrolysis, thus decreasing the concentration of the active GTP-bound form. This is balanced by GEF proteins that facilitate the exchange of GTP for GDP on the GTPase, thereby increasing the concentration of the GTP-bound form. In addition, guanine nucleotide dissociation inhibitor (GDI) proteins have also been implicated in negative regulation of some G-proteins (for review, see Hall and Zerial 1995). The identities of the GAP, GEF, and any GDIs that regulate Spglp are currently unknown.

Cdc16 and byr4 are potential negative regulators of Spglp, as loss of function mutants result in multiple rounds of septum formation. Cdcl6p and its $S$. cerevisiae homolog Bub2p have been shown previously to share a region of sequence homology with a family of functionally uncharacterized proteins (Richardson and Zon 1995). Sensitive database searches using the generalized profile technique (Bucher et al. 1996) found several new members of this domain family, shown in Figure 8A. Interestingly, two of these new members, Gyp6p and Gyp7p from S. cerevisiae, have been shown to be GAPs for small G-proteins of the Rab subfamily (Strom et al. 1993). Although phylogenetic analysis shows that Spglp is not a member of the Rab subfamily (Fig. 1B), residues
38-47 of Spglp show a remarkable similarity to the Rab family. In analogy to Ras proteins, this region may mediate interaction with the GAP (Bourne et al. 1991). It is possible that Cdc16p may be the GAP for Spglp, or a subunit thereof. This will be tested in future experiments.

The predicted byr4 protein has no significant homologies, with the exception of a small region of similarity with Cdc7p (Song et al. 1996). Because increased expression of $c d c 7$ and byr4 have opposite effects on septum formation (Fankhauser and Simanis 1994; Song et al. 1996), it is possible that these two proteins compete for binding to Spg1p. Alternatively, Byr4p may act by stimulating the GAP activity of Cdc16p, or inhibit the Cdc7pSpglp complex directly.

A model for how spg1 and the other genes required for the onset of septation may interact is shown in Figure $8 \mathrm{~B}$. Activation of Spglp GTPase by either inactivation of the GAP, activation of the GEF, or both, signals the initiation of septum formation, through the Cdc7p kinase. The catalytic domain of $c d c 7$ is related most closely to mitogen-associated protein (MAP) kinase-kinase-kinase (Fankhauser and Simanis 1994), suggesting the existence of a MAP kinase signaling module regulating septum formation. Studies of $S$. cerevisiae and $S$. pombe have implicated MAP kinase modules in the control of mating and bud-site selection, as well as stress and metabolic responses (for review, see Block and Wittinghofer 1995; Kron and Gow 1995; Roemer et al. 1996). The identity of the other kinases that might act in such a cascade in $S$. pombe is presently unknown.

Cells are far more sensitive to increases in Spglp expression than to the two other known inducers of septum formation, Cdc7p (Fankhauser and Simanis 1994) and Plolp (Ohkura et al. 1995). If there is a signal transduction cascade controlling the onset of septation, this may indicate that $S p g 1 \mathrm{p}$ is nearer to the top of it than either Cdc $7 p$ or Plolp. Alternatively, activation of Spglp may be rate limiting for septum formation, therefore small increases in its dosage produce a strong effect. In this context, an interesting analogy may be drawn with the mitotic inhibitor wee $1^{+}$, which produces a dosagedependent delay upon entry into mitosis (Russell and Nurse 1987).

LTE1 encodes the putative GEF for Temlp, and increased expression of TEM1 suppresses the requirement for LTE1 (Shirayama et al. 1994b). No GEF equivalent to LTE1 has yet been identified in S. pombe. Data in this study and previous studies (Fankhauser and Simanis 1994) show that increased expression of either $c d c 7$ or spg1 will rescue mutations in $c d c 11$. It is also noteworthy that an activated allele of $C D C 15$ rescues an 1te1 mutant (Shirayama et al. 1996). Although the $c d c 11$ gene has not been cloned to date, it is tempting to speculate that Cdc1 $1 p$ will be either the GEF for Spg1p, or a regulator of it. In this context, an analogy may be drawn with $S$. cerevisiae, where increased expression of $C D C 42$ rescues mutations in its GEF CDC24 (Bender and Pringle 1989).

Analysis of double mutants in this and previous stud- 


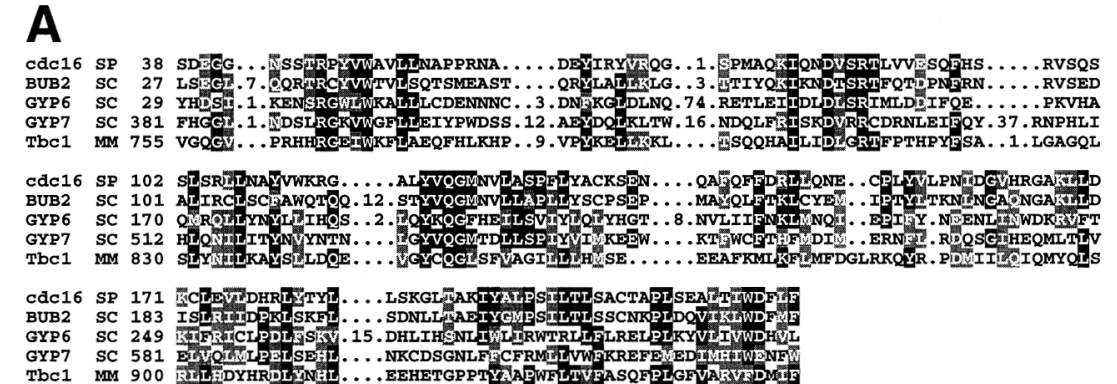

Figure 8. Similarity between Cdcl6p and GAP proteins, and a model for the control of septum formation in $S$. pombe. (A) An alignment of Cdc16p and Bup2p with GAP proteins. Positions conserved in $>50 \%$ of the sequences are shaded in black, positions containing conservative replacements are shaded. Large insertions in the alignments are indicated by gaps; the number of residues omitted is indicated. (SP) S. pombe; $(\mathrm{SC})$ S. cerevisiae; $(\mathrm{MM})$ mouse. $(B)$ A model for the regulation of septum formation in $S$. pombe. For further details, see text. The dotted line linking spg1 and $c d c 14$ indicates the strong genetic interactions between the spg1 and $c d c 14$ mutants. The double lines linking Spglp and Cdc7p indicate their physical association. Question marks indicate the multiple possible roles of byr 4 discussed in the text.

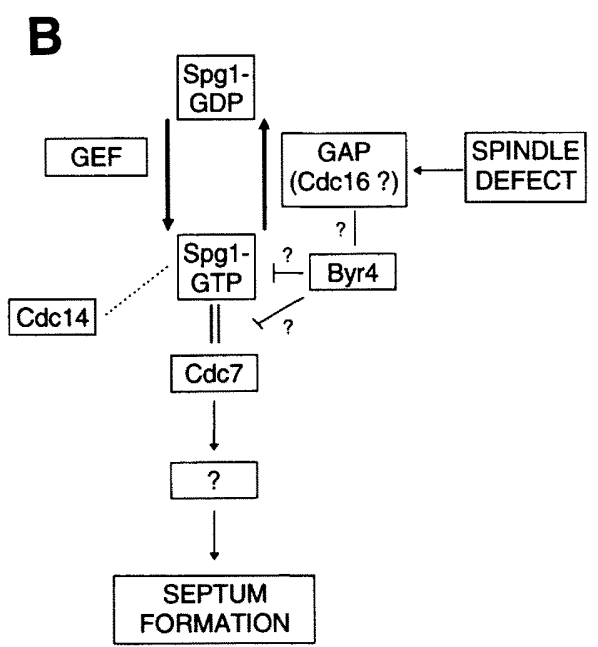

better how it interacts with the other components of this system.

Finally, this model also provides the potential for coordinating mitosis with septum formation. Cdc16p is implicated in the function of the spindle assembly checkpoint (Fankhauser et al. 1993), and Bub2p is thought to be one of the end points of the spindle assembly checkpoint signal transduction pathway (Wells 1996). Therefore, it is possible that activation of Cdc16p, in response to a spindle defect, would block septum formation by inhibiting Spglp signaling. Because Tem 1p is required for exit from mitosis, Bub2p may be the GAP for Temlp. Future studies will be directed to testing this model, and to identifying additional components of the signaling pathway.

\section{Materials and methods}

Yeast techniques

Standard techniques were used for growth, manipulation, and synchronization of fission yeast (Moreno et al. 1991). A list of strains used is given in Table 3. Cells were grown in yeast extract (YE) or EMM2 minimal medium, supplemented as required. Selection synchrony was performed using a Beckman JS 5.0 elutriation system. Other techniques have been referred to previously (Fankhauser et al. 1995). All mutants were outcrossed to wild-type at least twice before use. Crosses of a stable integrant of the spg1 gene (such that the site of integration was marked with the $u r a 4^{+}$selectable marker on the plasmid) with 
Table 3. List of strains used in this study

\begin{tabular}{|c|c|c|}
\hline Strain & Genotype & Reference \\
\hline SP0007 & $1 e n 1-32 h$ & Nurse et al. (1976) \\
\hline $\mathrm{SP} 0007 / 7$ & leu1-32 $h^{-}$pREP41(LEU2)-cdc7HA(ura4 $\left.{ }^{+}\right)$ & this study \\
\hline SP0560 & ade6M210/ade6M216 leu1-32/1eu1-32 ura4D18/ura4D18 $\mathrm{h}^{+} / \mathrm{h}^{-}$ & this study \\
\hline SP1684 & cdc7-24 leu1::pint5(ura4 $\left.{ }^{+}\right)-c d c 7(K 38 R)$ ura4D18 $\mathrm{h}^{-}$ & this study \\
\hline SP1724 & cdc7HA(ura4 $\left.4^{+}\right)$ura $4 D 18 \mathrm{~h}^{-}$ & this study \\
\hline SP1805 & leu1::pint5(ura4+)-spg1 ura4D18 $\mathrm{h}^{-}$ & this study \\
\hline SP1805/7 & leu1::pint5 $\left(\mathrm{ura4}^{+}\right)$-spg1 ura4D18 $\mathrm{h}^{-}$pREP41(LEU2)-cdc7 & this study \\
\hline SP1806 & cdc7-24 leu1::pint5(ura4 $\left.4^{+}\right)$-spg1 ura4D18 $\mathrm{h}^{-}$ & this study \\
\hline SP1807 & cdc11-136 leu1::pint5(ura $\left.4^{+}\right)$-spg1 ura4D18 $\mathrm{h}^{-}$ & this study \\
\hline SP1808 & 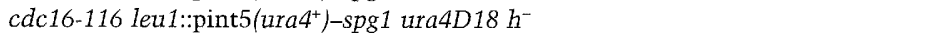 & this study \\
\hline SP1815 & spg1::ura4 $/$ spg1+ ade6M210/ade6M216 leu1- 32/leu1-32 ura4D18/ura4D18 $\mathrm{h}^{+} / \mathrm{h}^{-}$ & this study \\
\hline SP1881 & cdc15-140 leu1::pint5(ura4 $\left.{ }^{+}\right)$-spg1 ura4D18 $\mathrm{h}^{-}$ & this study \\
\hline SP1884 & cdc14-118 leu1::pint5(ura4 $4^{+}$)-spg1 ura4D18 $\mathrm{h}^{-}$ & this study \\
\hline SP1887 & cdc2-17 leu1::pint5(ura4+)-spg1 ura4D18 $\mathrm{h}^{-}$ & this study \\
\hline SP1889 & cdc25-22 leu1::pint5(ura4 $\left.4^{+}\right)$-spg1 ura4D18 $\mathrm{h}^{-}$ & this study \\
\hline SP1930 & spg1::ura4 ${ }^{+}$ade6M210 leu1-32 ura4D18 $\mathrm{h}^{-}$pREP41(LEU2)-cdc7 & this study \\
\hline SP2076 & $\operatorname{spg} 1-B 8 h^{-}$ & this study \\
\hline SP2123 & $\operatorname{spg} 1-B 8 \mathrm{cdc} 7-A 20 \mathrm{~h}^{-}$ & this study \\
\hline SP2129 & spg1-B8 cdc7-24 $\mathrm{h}^{-}$ & this study \\
\hline SP2137 & $\operatorname{spg} 1-B 8 \mathrm{cdc} 15-140 \mathrm{~h}^{-}$ & this study \\
\hline SP2138 & $\operatorname{spg} 1-B 8 \mathrm{cdc} 14-118 \mathrm{~h}^{+}$ & this study \\
\hline SP2143 & $\operatorname{spg} 1-B 8 \mathrm{cdc} 11-136 \mathrm{~h}^{-}$ & this study \\
\hline SP2149 & $\operatorname{spg} 1-B 8 \operatorname{cdc} 16-116 \mathrm{~h}^{-}$ & this study \\
\hline SP2155 & $\operatorname{spg} 1-B 8 \operatorname{cdc} 3-6 h^{-}$ & this study \\
\hline SP2157 & $\operatorname{spg} 1-B 8 \mathrm{cdc} 4-8 \mathrm{~h}^{-}$ & this study \\
\hline SP2159 & $\operatorname{spg} 1-B 8 \mathrm{cdc} 8-110 \mathrm{~h}^{-}$ & this study \\
\hline SP2161 & $\operatorname{spg} 1-B 8$ cdc12-112 $h^{-}$ & this study \\
\hline SP2163 & $\operatorname{spg} 1-B 8 d m f 1-6 h^{-}$ & this study \\
\hline SP2191 & cdc12-112 leu1::pint5(ura4 $\left.{ }^{+}\right)$-spg1 ura4D18 $\mathrm{h}^{-}$ & this study \\
\hline SP2192 & cdc8-110 leu1::pint5(ura4+)-spg1 ura4D19 $\mathrm{h}^{-}$ & this study \\
\hline SP2194 & cdc10-V50 leu1::pint5 $\left(\right.$ ura $\left.^{+}\right)$-spg1 ura4D18 $\mathrm{h}^{-}$ & this study \\
\hline SP2216 & wee1-50 leu1::pint5(ura4+)-spg1 ura4D18 $\mathrm{h}^{-}$ & this study \\
\hline SP2217 & cdc3-6 leu1::pint5(ura4 $4^{+}$)-spg1 ura4D18 $\mathrm{h}^{-}$ & this study \\
\hline SP2232 & cdc4-8 leu1::pint5(ura4 ${ }^{+}$)-spg1 ura $4 \mathrm{D} 18 \mathrm{~h}^{-}$ & this study \\
\hline CTY10-5d & MATa his3-200 trp1-901 leu2-3,112 ade2 URA3::(lexA op $\left._{8}\right)_{8}-\mathrm{lacZ}$ GAL4 gal80 & $\begin{array}{l}\text { M. Cardenas (Duke University, } \\
\text { Durham, NC) }\end{array}$ \\
\hline
\end{tabular}

The original mutants used in crosses have been described previously: wee1-50 (Nurse 1975); cdc3-6, cdc4-8, cdc7-24, cdc8-110, cdc11-136, cdc12-112, cdc14-118, and cdc15-140 (Nurse et al. 1976); cdc16-116 (Minet et al. 1979); cdc25-22 (Thuriaux et al. 1980); cdc10-V50 (Reymond et al. 1992); cdc7-A20 (Fankhauser and Simanis 1994); cdc2-17 (MacNeill et al. 1991); dmf1-6 (Sohrmann et al. 1996). Auxotrophic markers (leu1-32, ura4D198, ade6M210, and ade6M216) were crossed into these backgrounds as required.

the heat-sensitive $\operatorname{spg} 1-B 8$ ura4D18 mutant produced no $\mathrm{ura}^{+}$ $c d c^{-}$progeny in 65 tetrads analyzed. In addition, the $s p g 1-B 8$ mutant is rescued by introduction of the spg1 gene on a plasmid.

\section{DNA techniques}

Standard methods were used throughout for DNA manipulation (Sambrook et al. 1989). A S. pombe genomic DNA library from a cdc11-136 ura4D18 strain was constructed as described in Barbet et al. (1992). Genomic DNA extracted from $c d c 11-136$ ura 4 D18 cells was digested partially with Sau3A. Fragments between 4 and $9 \mathrm{~kb}$ were selected by gel purification, and the ends partially filled in using dATP and dGTP. These were cloned into Sall-digested pURL18 vector whose ends had been filled in partially with dCTP and dTTP. The pURL 18 vector was derived from pUR18 (Barbet et al. 1992) by insertion of the $S$. pombe leu1 gene (Kikuchi et al. 1988), as a DraI fragment, into the unique NarI site between the polylinker and the ura4 gene.

A culture of SP1684 cells was transformed to leucine prototrophy (Moreno et al. 1991) with this library.

\section{Spgl deletion}

A null allele of the $\operatorname{spg} 1$ gene was created by replacing the Bg7IIHindIII fragment in the genomic clone with the ura4 gene. A diploid strain (SP0560) was constructed mating ade6M210 and ade6M216 strains, which complement in trans. This diploid was transformed with a $2.2-\mathrm{kb}$ linear PstI fragment containing the deletion of $\operatorname{spg} 1$ to make the diploid SP1815. Correct integration was verified by Southern blot analysis. Genomic DNA was prepared from wild-type diploid cells (SP0560), from the diploid heterozygous for the spg1 deletion (SP1815), and from the haploid spg1::ura4 ${ }^{+}$strain covered by the $c d c 7$ plasmid (SP1930), and digested with EcoRV. The Southern blot was probed with a $1.5-\mathrm{kb}$ ClaI fragment, located adjacent to the spg1 open reading frame (ORF).

\section{Oligonucleotide-directed mutagenesis}

To introduce point mutations in the spg1 gene, in vitro sitedirected mutagenesis was performed, using the CLONTECH laboratories kit, following the standard protocol (Deng and Nickoloff 1992). A 958-bp DraI fragment of the spg1 cDNA, which begins 5 bp before the ATG codon, was cloned into the SmaI site of pDW232 (Weilguny et al. 1991). The following oligonucleotides were used, each together with VS106, which changes the SalI site in the polylinker to XhoI. Extensive digestion with Sall was used to enrich for mutagenized plasmids. All mutants were recloned and sequenced before use. Inserts were 
excised from pDW232 with EcoRI and BamHI (both in the polylinker), treated with Klenow fragment, and cloned into pREP3, pREP41, or pREP81 (Basi et al. 1993), which had been digested with NdeI and treated with Klenow fragment. VS106, 5'-GCCTGCAGCTCGAGTCTAGAGG-3'; T24N, 5' -CCATAAGAGAATTTTTGCCAAT-3'; Q69L， 5'-CAAATTCTCGCAGACCTCCAAG-3'; D125A, 5'-CATGAAATGAGCGTATTTTG-3'; T42A, 5'-GGAAAGCACACAAGCGCTTGGAG-3'.

Integration of $\mathrm{spg} 1$ and $\mathrm{cdc} 7(K 38 R) \mathrm{nmtl}$ expression cassettes into the $\mathrm{S}$. pombe genome

The strains SP1805 and SP1684, which carry a single integrated copy of the spg 1 gene or $c d c 7(\mathrm{~K} 38 \mathrm{R})$ under the control of the nmt1 promoter in the pINT5 vector, were created as described in Fankhauser and Simanis (1994). The EcoRI-BamHI fragment described above was cloned into BamHI-digested pINT5, after treatment of both vector and insert with Klenow fragment. The plasmid was digested with NotI, and the resulting linear fragment comprising the spg1 gene flanked by the leu $1^{+}$gene and the $u r a 4^{+}$gene was purified and used to transform a ura4D18 strain. Cells were plated onto minimal medium supplemented with leucine and thiamine. Integrants at the leu1 locus were identified by replica plating uracil prototrophs onto minimal medium. Correct integration was verified by Southern blotting. Similar techniques were used to integrate the spg1 gene into $c d c 2-17, c d c 10-V 50, c d c 25-22$, wee1-50, cdc4-8, cdc3-6, and $c d c 7-24$ backgrounds. The nmt1-spg1 expression cassette was introduced into other backgrounds by crossing appropriate yeast strains and dissection of tetrads.

\section{Antisera, protein extracts, and immunoprecipitations}

A synthetic peptide corresponding to the carboxy-terminal 19 amino acids of Spglp (CTIPEIKNVGDPILEYIDR) was coupled to Keyhole Limpet Hemocyanin $\left(\mathrm{KLH}_{\text {; }}\right.$ Sigma), using $m$-maleimidobenzoyl- $N$-hydroxysuccinimide ester (MBS) as described (Harlow and Lane 1988). Ten milligrams of peptide were coupled to $10 \mathrm{mg}$ of $\mathrm{KLH}$ in a $1.5-\mathrm{ml}$ reaction. Uncoupled peptide was removed by extensive dialysis against PBS. Approximately $200 \mu \mathrm{g}$ of peptide-conjugated $\mathrm{KLH}$, emulsified in incomplete Freund's adjuvant, were injected monthly into New Zealand white rabbits. Standard procedures were used throughout for antibody production (Harlow and Lane 1988). For affinity purification, the peptide was coupled to $\mathrm{CNBr}$-activated Sepharose (Pharmacia). The protocol for affinity purification has been described previously (Harlow and Lane 1988). For Western blotting, bound antibodies were detected using peroxidasecoupled secondary antibodies and revealed with enhanced chemiluminescence (ECL) (Amersham), or with alkaline phosphatase-coupled secondary antibodies. Protein extracts and immunoprecipitations were performed as previously described (Fankhauser and Simanis 1994), except that affinity-purified spg1 antibody and the 12CA5 monoclonal antibody were used.

\section{Microscopy}

Staining with DAPI, Calcofluor, and rhodamine-conjugated phalloidin was performed according to Marks and Hyams (1985). Staining for Cdc15p (Fankhauser et al. 1995) and tubulin (Hagan and Hyams 1988) have been described elsewhere. Microtubules were stained using TAT-1 (Woods et al. 1989).

\section{Two-hybrid assay}

The $c d c 7$ cDNA was cloned into the LexA fusion vector pBTM116 (constructed and provided by P. Bartel and S. Fields,
State University of New York, Stony Brook). The spg $1^{+}$and spg1(T42A) cDNAs were cloned into the Gal4 activation domain fusion vector pGAD10 (Clontech). Plasmids were introduced into the strain CTY10-5d, which was obtained from $M$. Cardenas (Duke University, Durham, NC). Quantitative $\beta$-galactosidase assays were performed as follows: Single colonies from yeast transformants were grown to saturation in selective synthetic medium, diluted 20 -fold into fresh medium, and grown to an $\mathrm{OD}_{600}$ of $0.5-0.8$ at $30^{\circ} \mathrm{C}$. One milliliter of culture was washed once in $Z$ buffer (Miller 1972) and then resuspended in $0.15 \mathrm{ml}$ of $\mathrm{Z}$ buffer. After addition of $0.05 \mathrm{ml}$ of $\mathrm{CHCl}_{3}$ and $0.02 \mathrm{ml}$ of $0.1 \%$ SDS, the cell suspension was vortexed. The remainder of the assay, and calculation of Miller units of activity were as described (Miller 1972). All assays were performed in triplicate, from three independent transformants, and normalized to the $\mathrm{OD}_{600}$ of the culture.

\section{Construction of the 7HA strain}

To tag the $c d c 7$ gene at its carboxyl terminus, the genomic clone in pDW232 (Weilguny et al. 1991; Fankhauser and Simanis 1994) was digested with BstXI. The oligonucleotides ATGCGGCCGCTAG and CGGCCGCATCTAG were phosphorylated, annealed, and ligated into the BstXI site to create a NotI site. The resulting plasmid was digested with NotI, and a triple HA tag cassette was inserted (Tyers et al. 1992). The ura4 ${ }^{+}$gene and $1.5 \mathrm{~kb}$ of genomic sequence downstream of the $c d c 7^{+}$gene were cloned, in this order, behind the tag into sites in the polylinker of pDW232. The whole insert was then excised from the vector and transformed as a linear fragment into a ura $4 D 18$ strain. Stable uracil prototrophs were checked by Southern and Western blotting for correct replacement of the $c d c 7^{+}$gene by the tagged version.

\section{Acknowledgments}

We thank Bernhard Hirt and Michel Aguet for financial support and encouragement, and Marcel Allegrini for photography. We are also grateful to Nicola Beltraminelli, Lorenzo Cerutti, Christian Fankhauser, Maximilien Murone, and Suzan Utzig for discussions and reading the manuscript, and to Elena Cano for technical assistance. We are also grateful to Christian Fankhauser for creating the cdc7HA strain. We thank Keith Gull (Manchester University) for the gift of TAT-1 antibody and Paul Nurse for spg1-B8, and Akio Toh-e for TEM1 and LTE1 plasmids. This work was funded by grants from the Ligue Suisse contre le Cancer and the Swiss National Science foundation to V.S., and by the ICRF.

The publication costs of this article were defrayed in part by payment of page charges. This article must therefore be hereby marked "advertisement" in accordance with 18 USC section 1734 solely to indicate this fact.

\section{References}

Arellano, M., A. Duran, and P. Perez. 1996. Rho1 GTPase activates the 1-3 $\beta$-D glucan synthase and is involved in Schizosaccharomyces pombe morphogenesis. EMBO J. 15: 45844591.

Balasubramanian, M.K., D.M. Helfman, and S.M. Hemmingsen. 1992. A new tropomyosin essential for cytokinesis in the fission yeast $S$. pombe. Nature 360: 84-87.

Balasubramanian, M.K., B.R. Hirani, J.D. Burke, and K.L. Gould. 1994. The Schizosaccharomyces pombe cdc3 gene encodes a profilin essential for cytokinesis. J. Cell Biol. 125: 12891301 . 
Barbet, N., W.J. Muriel, and A.M. Carr. 1992. Versatile shuttle vectors and genomic libraries for use with Schizosaccharomyces pombe. Gene 114: 59-66.

Basi, G., E. Schmid, and K. Maundrell. 1993. TATA box mutations in the Schizosaccharomyces pombe nmt1 promoter affect transcription efficiency but not the transcription start point or thiamine repressibility. Gene 123: 131-136.

Bender, A. and J.R. Pringle. 1989. Multicopy suppression of the $c d c 24$ budding defect in yeast by CDC42 and three newly identified genes including the ras-related gene RSR1. Proc. Natl. Acad. Sci. 86: 9976-9980.

Block, C. and A. Wittinghofer. 1995. Switching to Rac and Rho. Structure 3: 1281-1284.

Bourne, H.R., D.A. Sanders, and F. McCormick. 1991. The GTPase superfamily: Conserved structure and molecular mechanism. Nature 349: 117-127.

Bucher, P., K. Karplus, N. Moeri, and K. Hofmann. 1996. A flexible motif search technique based on generalized profiles. Comp. Chem. 20: 3-23.

Chang, E.C., M. Barr, Y. Wang, V. Jung, H. Xu, and M. Wigler. 1994. Cooperative interaction of $S$. pombe proteins required for mating and morphogenesis. Cell 79: 131-141.

Chang, F. and P. Nurse. 1996. How fission yeast fission in the middle. Cell 84: 191-194.

Chang, F., A. Woollard, and P. Nurse. 1996. Isolation and characterization of fission yeast mutants defective in the assembly and placement of the contractile actin ring. J. Cell Sci. 109: 131-142.

Chen, Y.T., C. Holcomb, and H.P. Moore. 1993. Expression and localization of two low molecular mass GTP-binding proteins, Rab8 and Rab10, by epitope tag. Proc. Natl. Acad. Sci. 90: 6508-6512.

Deng, W.P. and J.A. Nickoloff. 1992. Site-directed mutagenesis of virtually any plasmid by eliminating a unique site. Anal. Biochem. 200: 81-88.

Durfee, T., K. Becherer, P.L. Chen, S.H. Yeh, Y. Yang, A.E. Kilburn, W.H. Lee, and S.J. Elledge. 1993. The retinoblastoma protein associates with the protein phosphatase type 1 catalytic subunit. Genes \& Dev. 7: 555-569.

Fankhauser, C. and V. Simanis. 1993. The Schizosaccharomyces pombe cdc14 gene is required for septum formation and can also inhibit nuclear division. Mol. Biol. Cell 4: 531-539.

- 1994. The $c d c 7$ protein kinase is a dosage-dependent regulator of septum formation in fission yeast. EMBO $\mathrm{J}$. 13: 3011-3019.

Fankhauser, C., J. Marks, A. Reymond, and V. Simanis. 1993. The $S$. pombe cdc16 gene is required both for maintenance of p34 ${ }^{c d c 2}$ kinase activity and regulation of septum formation, a link between mitosis and cytokinesis? EMBO J. 12: 26972704.

Fankhauser, C., A. Reymond, L. Cerutti, S. Utzig, K. Hofmann, and V. Simanis. 1995. The $S$. pombe cdc15 gene is a key element in the reorganisation of F-actin at mitosis. Cell 82: 435-444.

Fishkind, D.J. and Y. Wang. 1995. New horizons for cytokinesis. Curr. Opin. Cell Biol. 7: 23-31.

Forsburg, S.L. and P. Nurse. 1991. Cell cycle regulation in the yeasts Saccharomyces cerevisiae and Schizosaccharomyces pombe. Annu. Rev. Cell Biol. 7: 227-256.

Hagan, I.M. and J.S. Hyams. 1988. The use of cell division cycle mutants to investigate the control of microtubule distribution in the fission yeast Schizosaccharomyces pombe. I. Cell Sci. 89: 343-357.

Hall, A. 1994. Small GTP-binding proteins and the regulation of the actin cytoskeleton. Annu. Rev. Cell Biol. 10: 31-54.

Hall, A. and M. Zerial. 1995. A guidebook to the small GTPases (ed. M. Zerial and L.A. Huber|, pp. 3-11. Oxford University Press, Oxford, UK.

Harlow, E. and D. Lane. 1988. Antibodies. A laboratory manual. Cold Spring Harbor Laboratory, Cold Spring Harbor, NY.

Hayles, J., D. Fisher, A. Woollard, and P. Nurse. 1994. Temporal order of $\mathrm{S}$ phase and mitosis in fission yeast is determined by the state of the p34cdc2-mitotic B cyclin complex. Cell 78: 813-822.

Hirano, T., S. Funahashi, T. Uemura, and M. Yanagida. 1986. Isolation and characterization of Schizosaccharomyces pombe cut mutants that block nuclear division but not cytokinesis. $E M B O$ J. 5: 2973-2979.

Hughes, D.A. 1995. Control of signal transduction and morphogenesis by Ras. Semin. Cell Biol. 6: 89-94.

Kelly, T.J., G.S. Martin, S.L. Forsburg, R.J. Stephen, A. Russo, and P. Nurse. 1993. The fission yeast $c d c 18^{+}$gene product couples S-phase to START and mitosis. Cell 74: 371-382.

Kikuchi, Y., Y. Kitazawa, H. Shimatake, and M. Yamamoto. 1988. The primary structure of the $l e u 1^{+}$gene of Schizosaccharomyces pombe. Curr. Genet. 14: 375-379.

Kitada, K., A.L. Johnson, L.H. Johnston, and A. Sugino. 1993. A multicopy suppressor gene of the Saccharomyces cerevisiae $\mathrm{G}_{1}$ cell cycle mutant gene dbf 4 encodes a protein kinase and is identified as CDC5. Mol. Cell. Biol. 13: 4445-4457.

Kron, S.J. and N.A.R. Gow. 1995. Budding yeast morphogenesis, signaling, cytoskeleton and cell cycle. Curr. Opin. Cell Biol. 7: 845-855.

Larochelle, D.A., K.K. Vithalani, and A. De Lozanne. 1996. A novel member of the rho family of small GTP binding proteins is specifically required for cytokinesis. J. Cell Biol. 133: 1321-1329.

Leevers, S.J., H.F. Paterson, and C.J. Marshall. 1994. Requirement for Ras in Raf activation is overcome by targetting Raf to the plasma membrane. Nature 369: 411-414.

Mabuchi, I., Y. Hamaguchi, H. Fujimoto, N. Morii, M. Mishimia, and S. Narumija. 1993. A rho-like protein is involved in the organization of the contractile ring in dividing sand dollar eggs. Zygote 1: 325-331.

MacNeill, S.A., J. Creanor, and P. Nurse. 1991. Isolation, characterization and molecular cloning of new mutant alleles of the fission yeast $\mathrm{p} 34 \mathrm{cdc} 2+$ protein kinase gene: Identification of temperature-sensitive $\mathrm{G}_{2}$-arresting alleles. Mol. Gen. Genet. 229: 109-118.

Marcus, S., A. Polverino, E. Chang, D. Robbins, M. Cobb, and M. Wigler. 1995. Shk1, a homolog of the S. cerevisiae Ste20 and mammalian $\mathrm{p} 65^{\mathrm{PAK}}$ protein kinases, is a component of a Ras/Cdc42 signaling module in the fission yeast Schizosaccharomyces pombe. Proc. Nat1. Acad. Sci. 92: 6180-6184.

Marks, J. and J.S. Hyams. 1985. Localization of F-actin through the cell division cycle of Schizosaccharomyces pombe. Eur. I. Cell Biol. 39: 27-32.

Marks, J., C. Fankhauser, and V. Simanis. 1992. Genetic interactions in the control of septation in Schizosaccharomyces pombe. J. Cell Sci. 101: 801-808.

McCollum, D., M.K. Balasubramanian, L.E. Pelcher, S.M. Hemmingsen, and K.L. Gould. 1995. The Schizosaccharomyces pombe $c d c 4+$ gene encodes a novel EF-hand protein essential for cytokinesis. J. Cell Biol. 130: 651-660.

Miller, J. 1972. Experiments in molecular genetics. Cold Spring Harbor Laboratory, Cold Spring Harbor, NY.

Miller, P.J. and D.I. Johnson. 1994. Cdc42p GTPase is involved in controlling polarized cell growth in Schizosaccharomyces pombe. Mol. Cell. Biol. 14: 1075-1083.

Minet, M., P. Nurse, P. Thuriaux, and J.M. Mitchison. 1979. Uncontrolled septation in a cell division cycle mutant of the 
fission yeast Schizosaccharomyces pombe. I. Bacteriol. 137: $440-446$.

Moreno, S., A. Klar, and P. Nurse. 1991. Molecular genetic analysis of fission yeast Schizosaccharomyces pombe. Methods Enzymol. 194: 795-823.

Nakano, K. and I. Mabuchi. 1995. Isolation and sequencing of two cDNA clones encoding Rho proteins from the fission yeast Schizosaccharomyces pombe. Gene 155: 119-122.

Nurse, P. 1975. Genetic control of cell size at cell division in yeast. Nature 256: 547-551.

Nurse, P., P. Thuriaux, and K. Nasmyth. 1976. Genetic control of the cell division cycle in the fission yeast Schizosaccharomyces pombe. Mol. \& Gen. Genet. 146: 167-178.

Ohkura, H., I.M. Hagan, and D.M. Glover. 1995. The conserved Schizosaccharomyces pombe kinase plol, required to form a bipolar spindle, the actin ring, and septum, can drive septum formation in $\mathrm{G}_{1}$ and $\mathrm{G}_{2}$ cells. Genes \& Dev. 9: 1059-1073.

Ottilie, S., P.J. Miller, D.I. Johnson, C.L. Creasy, M.A. Sells, S. Bagrodia, S.L. Forsburg, and J. Chernoff. 1995. Fission yeast pak $1+$ encodes a protein kinase that interacts with $\mathrm{Cdc} 42 \mathrm{p}$ and is involved in the control of cell polarity and mating. EMBO \%. 14: 5908-5919.

Peter, M., A.M. Neimann, H. Park, M. van Lohuizen, and I. Herskowitz. 1996. Functional analysis of the interaction between the small GTP binding protein Cdc42 and the Ste20 protein kinase in yeast. EMBO T. 15: 7046-7059.

Reymond, A., S. Schmidt, and V. Simanis. 1992. Mutations in the cdc10 START gene of Schizosaccharomyces pombe implicate the region of homology between $c d c 10$ and SWI6 as important for $\mathrm{p} 85^{\mathrm{cdc} 10}$ function. Mol. \& Gen. Genet. 234: 449-456.

Richardson, P.M. and L.I. Zon. 1995. Molecular cloning of a cDNA with a novel domain present in the tre- 2 oncogene and the yeast cell cycle regulators BUB2 and cdc16. Oncogene 11: 1139-1148.

Ridley, A.J. 1995. Rho-related proteins, actin cytoskeleton and cell cycle. Curr. Opin. Genet. Dev. 5: 24-30.

Robinow, C.F. and J.S. Hyams. 1989. General cytology of fission yeasts. In The molecular biology of the fission yeast led. A. Nasim, P.G. Young, and B.F. Johnson). pp. 273-331. Academic Press, New York, NY.

Roemer, T., L.G. Vallier, and M. Snyder. 1996. Selection of polarized growth sites in yeast. Trends Cell Biol. 6: 434-441.

Russell, P. and P. Nurse. 1986. $c d c 25^{+}$functions as an inducer in the mitotic control of fission yeast. Cell 45: 145-153.

- 1987. Negative regulation of mitosis by weelt, a gene encoding a protein kinase homolog. Cell 49: 559-567.

Saitou, N. and M. Nei. 1987. The neighbour-joining method. A new method for reconstructing phylogenetic trees. Mol. Biol. Evol. 4: 406-425.

Sambrook, J., E.F. Fritsch, and T. Maniatis. 1989. Molecular cloning, 2nd ed. Cold Spring Harbor Laboratory Press, Cold Spring Harbor, NY.

Samejima, I., T. Matsumoto, Y. Nakaseko, D. Beach, and M. Yanagida. 1993. Identification of seven new cut genes involved in Schizosaccharomyces pombe mitosis. I. Cell Sci. 105: 135-143.

Satterwhite, L.L. and T.D. Pollard. 1992. Cytokinesis. Curr. Opin. Cell Biol. 4: 43-52.

Shirayama, M., Y. Matsui, and A. Toh-e. 1994a. The yeast TEMl gene, which encodes a GTP-binding protein, is involved in termination of $M$ phase. Mol. Cell. Biol. 14: 7476 7482.

Shirayama, M., Y. Matsui, K. Tanaka, and A. Toh-e. 1994b. Isolation of a CDC25 family gene, MSI2/LTE1, as a multicopy suppressor of ira1. Yeast 10: 451-461.
Shirayama, M., Y. Matsui, and A. Toh-e. 1996. Dominant mutant alleles of yeast protein kinase gene CDC15 suppress the lte1 defect in termination of $\mathrm{M}$ phase and genetically interact with CDC14. Mol. Gen. Genet. 251: 176-185.

Sigal, I.S., J.B. Gibbs, J.S. D'Alonzo, and E.M. Scolnick. 1986. Identification of effector residues and a neutralizing epitope of Ha-ras-encoded p21. Proc. Nat1. Acad. Sci. 83: 4725-4729.

Simanis, V. 1995. The control of septum formation and cytokinesis in fission yeast. Semin. Cell Biol. 6: 79-87.

Sohrmann, M., C. Fankhauser, C. Brodbeck, and V. Simanis. 1996. The $d m f 1$ gene is essential for correct positioning of the division septum in fission yeast. Genes \& Dev. 10: $2707-$ 2720 .

Song, K., K.E. Mach, C.Y. Chen, T. Reynolds, and C.F. Albright. 1996. A novel suppressor of rasl in fission yeast, byr4, is a dosage-dependent inhibitor of cytokinesis. I. Cell Biol. 133: $1307-1319$

Strom, M., P. Vollmer, T.J. Tan, and D. Gallwitz. 1993. A yeast GTPase-activating protein that interacts specifically with a member of the ypt/rab family. Nature 361: 736-739.

Surana, U., A. Amon, C. Dowzer, J. McGrew, B. Byers, and K. Nasmyth. 1993. Destruction of the CDC28/CLB mitotic kinase is not required for the metaphase to anaphase transition in budding yeast. EMBO I. 12: 1969-1978.

Thuriaux, P., M. Sipiczki, and P.A. Fantes. 1980. Genetical analysis of a sterile mutant by protoplast fusion in the fission yeast Schizosaccharomyces pombe. J. Gen. Microbiol. 116: $525-528$.

Tyers, M., G. Tokiwa, R. Nash, and B. Futcher. 1992. The cln3cdc28 kinase complex of $S$. cerevisiae is regulated by proteolysis and phosphorylation. EMBO I. 11: 1773-1784.

Wells, W.A.E. 1996. The spindle-assembly checkpoint: Aiming for a perfect mitosis, every time. Trends Cell Biol. 6: 228234.

Weilguny, D., M. Praetorius, A. Carr, R. Egel, and O. Nielsen. 1991. New vectors in fission yeast: Application for cloning of the his2 gene. Gene 99: 47-54.

Wittinghofer, A. and A. Valencia. 1995. Three dimensional structure of ras and ras-related proteins. In A guidebook to the small GTPases (ed. M. Zerial and L.A. Huber), pp. 20-29. Oxford University Press, Oxford, UK.

Woods, A., T. Sherwin, R. Sasse, T.H. Macrae, A.J. Baines, and K. Gull. 1989. Definition of individual components within the cytoskeleton of Trypanosoma brucei by a library of monoclonal antibodies. J. Cell Sci. 93: 491-500. 


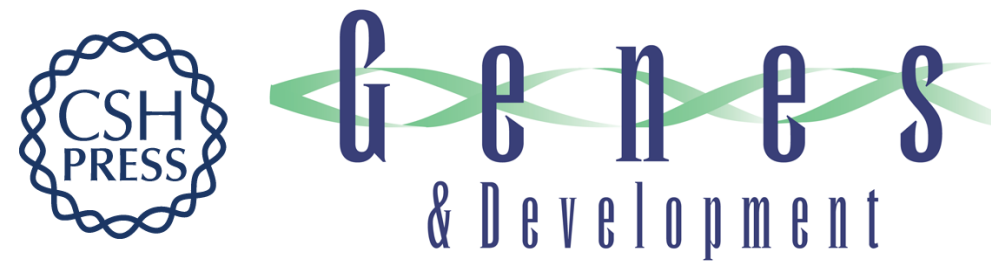

\section{The Spg1p GTPase is an essential, dosage-dependent inducer of septum formation in Schizosaccharomyces pombe.}

S Schmidt, M Sohrmann, K Hofmann, et al.

Genes Dev. 1997, 11:

Access the most recent version at doi:10.1101/gad.11.12.1519

References This article cites 70 articles, 21 of which can be accessed free at:

http://genesdev.cshlp.org/content/11/12/1519.full.html\#ref-list-1

License

Email Alerting

Service

Receive free email alerts when new articles cite this article - sign up in the box at the top right corner of the article or click here.

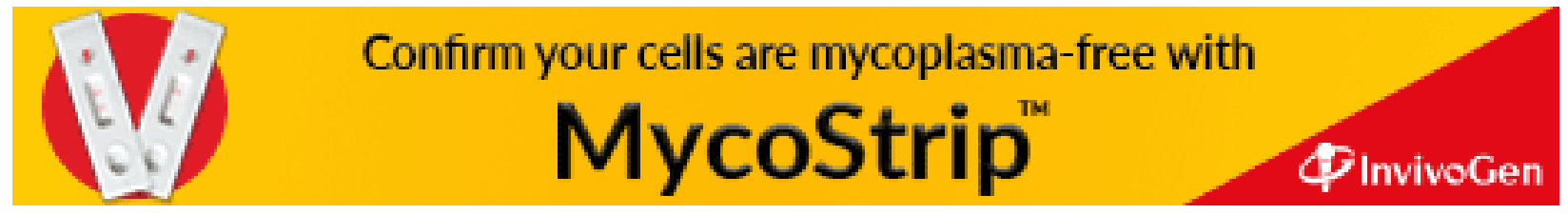

